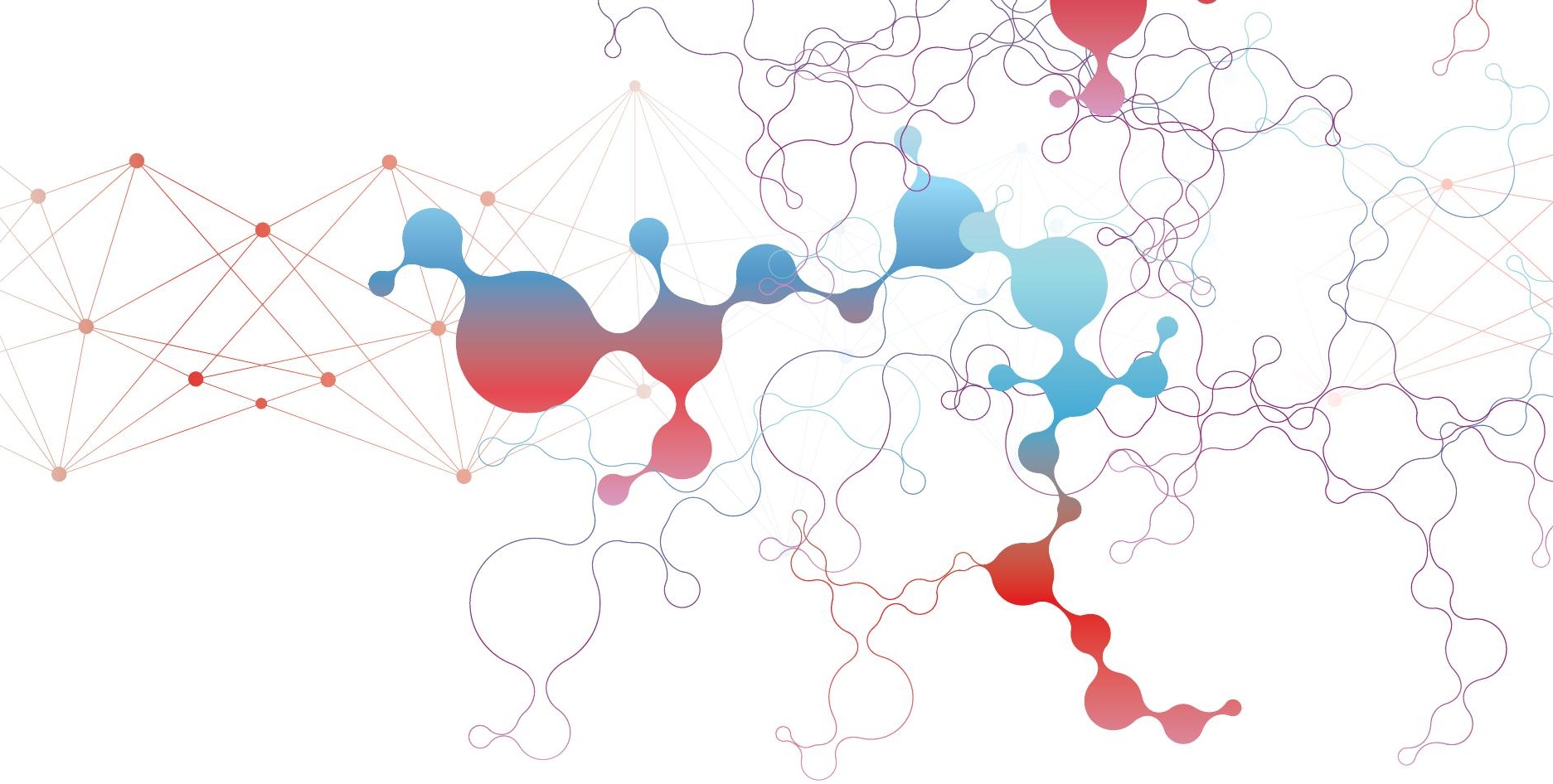

\title{
Report on the economic impact of coronavirus disease (COVID-19) on Latin America and the Caribbean
}

Study prepared by the Economic Commission for Latin America and the Caribbean (ECLAC), at the request of the Government of Mexico in its capacity as Pro Tempore Chair of the Community of Latin American and Caribbean States (CELAC), at the virtual ministerial meeting on health matters for response and follow-up to the COVID-19 pandemic in Latin America and the Caribbean, held on 26 March 2020

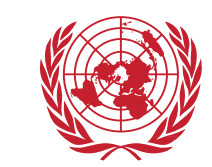

UNITED NATIONS

E C L \& C

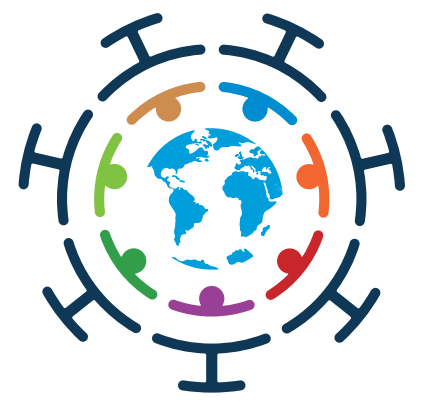

COVID-19 RESPONSE 


\section{Thank you for your interest in this ECLAC publication}

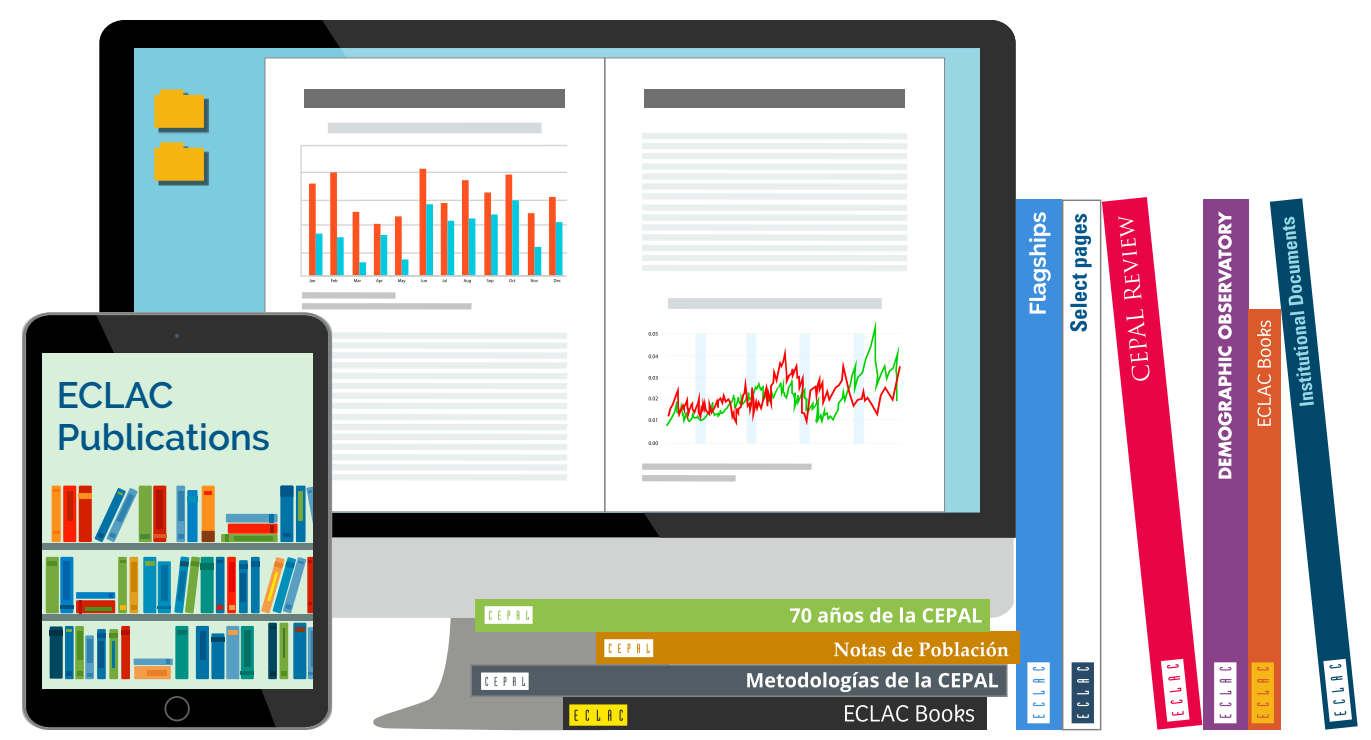

Please register if you would like to receive information on our editorial products and activities. When you register, you may specify your particular areas of interest and you will gain access to our products in other formats.

\section{Register}

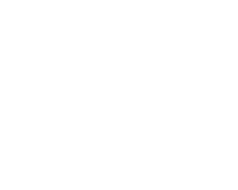

UNITED NATIONS E C L A C www.cepal.org/en/publications

facebook.com/publicacionesdelacepal

P www.cepal.org/apps 


\section{Report on the economic impact of coronavirus disease (COVID-19) on Latin America and the Caribbean}

Study prepared by the Economic Commission for Latin America and the Caribbean (ECLAC), at the request of the Government of Mexico in its capacity as Pro Tempore Chair of the Community of Latin American and Caribbean States (CELAC), at the virtual ministerial meeting on health matters for response and follow-up to the COVID-19 pandemic in Latin America and the Caribbean, held on 26 March 2020

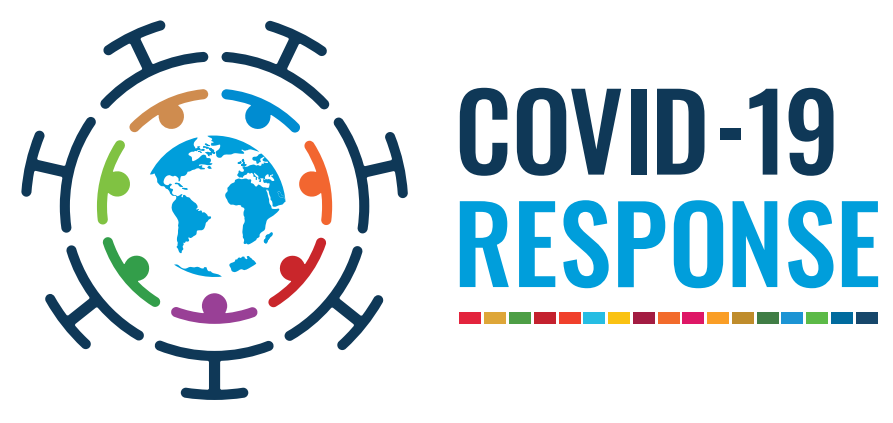




\section{Alicia Bárcena \\ Executive Secretary}

Mario Cimoli

Deputy Executive Secretary

Raúl García-Buchaca

Deputy Executive Secretary for Management and Programme Analysis

Ricardo Pérez

Chief, Publications and Web Services Division

This document was prepared by the Economic Commission for Latin America and the Caribbean (ECLAC), at the request of the Government of Mexico in its capacity as Pro Tempore Chair of the Community of Latin American and Caribbean States (CELAC), at the virtual ministerial meeting on health affairs for response and follow-up to the COVID-19 pandemic in Latin America and the Caribbean, held on 26 March 2020.

The boundaries and names shown on the maps included in this publication do not imply official endorsement or acceptance by the United Nations.

United Nations publication

LC/TS.2020/45

Distribution: L

Copyright (C) United Nations, 2020

All rights reserved

Printed at United Nations, Santiago

S.20-00312

This publication should be cited as: Economic Commission for Latin America and the Caribbean (ECLAC), Report on the economic impact of coronavirus disease (COVID-19) on Latin America and the Caribbean: study prepared by the Economic Commission for Latin America and the Caribbean (ECLAC), at the request of the Government of Mexico in its capacity as Pro Tempore Chair of the Community of Latin American and Caribbean States (CELAC), at the virtual ministerial meeting on health matters for response and follow-up to the COVID-19 pandemic in Latin America and the Caribbean, held on 26 March 2020, held on 26 March 2020 (LC/TS.2020/45), Santiago, 2020.

Applications for authorization to reproduce this work in whole or in part should be sent to the Economic Commission for Latin America and the Caribbean (ECLAC). Publications and Web Services Division, publicaciones.cepal@un.org. Member States and their governmental institutions may reproduce this work without prior authorization, but are requested to mention the source and to inform ECLAC of such reproduction. 


\section{Contents}

Report for the Community of Latin American and Caribbean States (CELAC) ..........................................

I. The economic and social impacts of the coronavirus disease (COVID-19) pandemic in Latin America

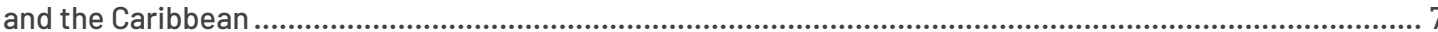

A. Before the pandemic, the region was already posting its lowest economic growth in decades

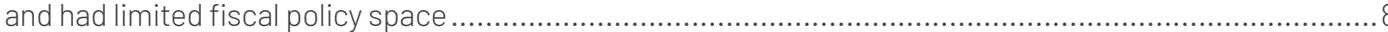

B. The pandemic will lead to the most severe contraction in economic activity in the region's history ............ 10

C. The Latin American and Caribbean economies in 2020: ECLAC projects a contraction of $5.3 \%$, adding almost 30 million to the number of poor .............................................................................. 13

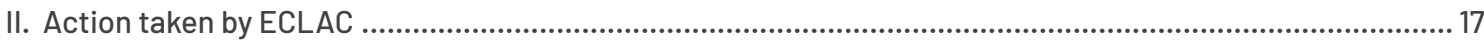

A. COVID-19 Observatory in Latin America and the Caribbean: economic and social impact .......................17

B. Knowledge Transfer Network of the Statistical Conference of the Americas: ideas and recommendations for the continuity of main statistical operations during the pandemic..................................................20

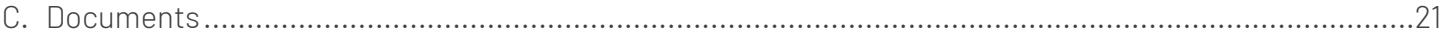

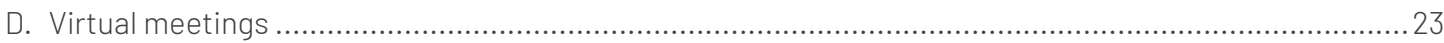

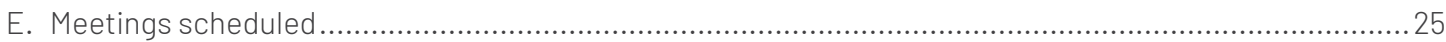

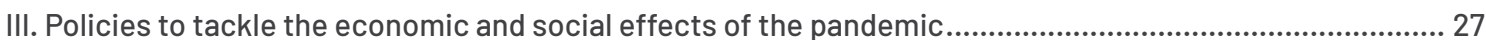

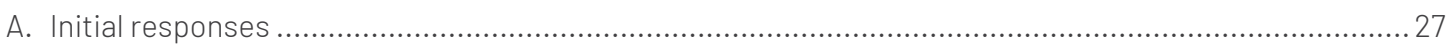

B. Policies for further progress in mitigating the effects of the crisis ..................................................30

C. Policies for structural change: creating the post-COVID world ........................................................31

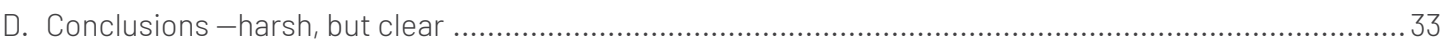

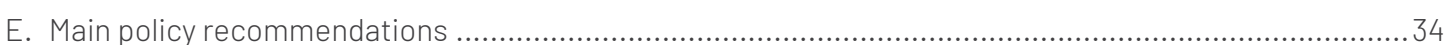

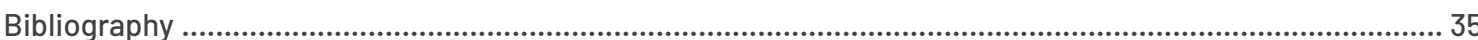





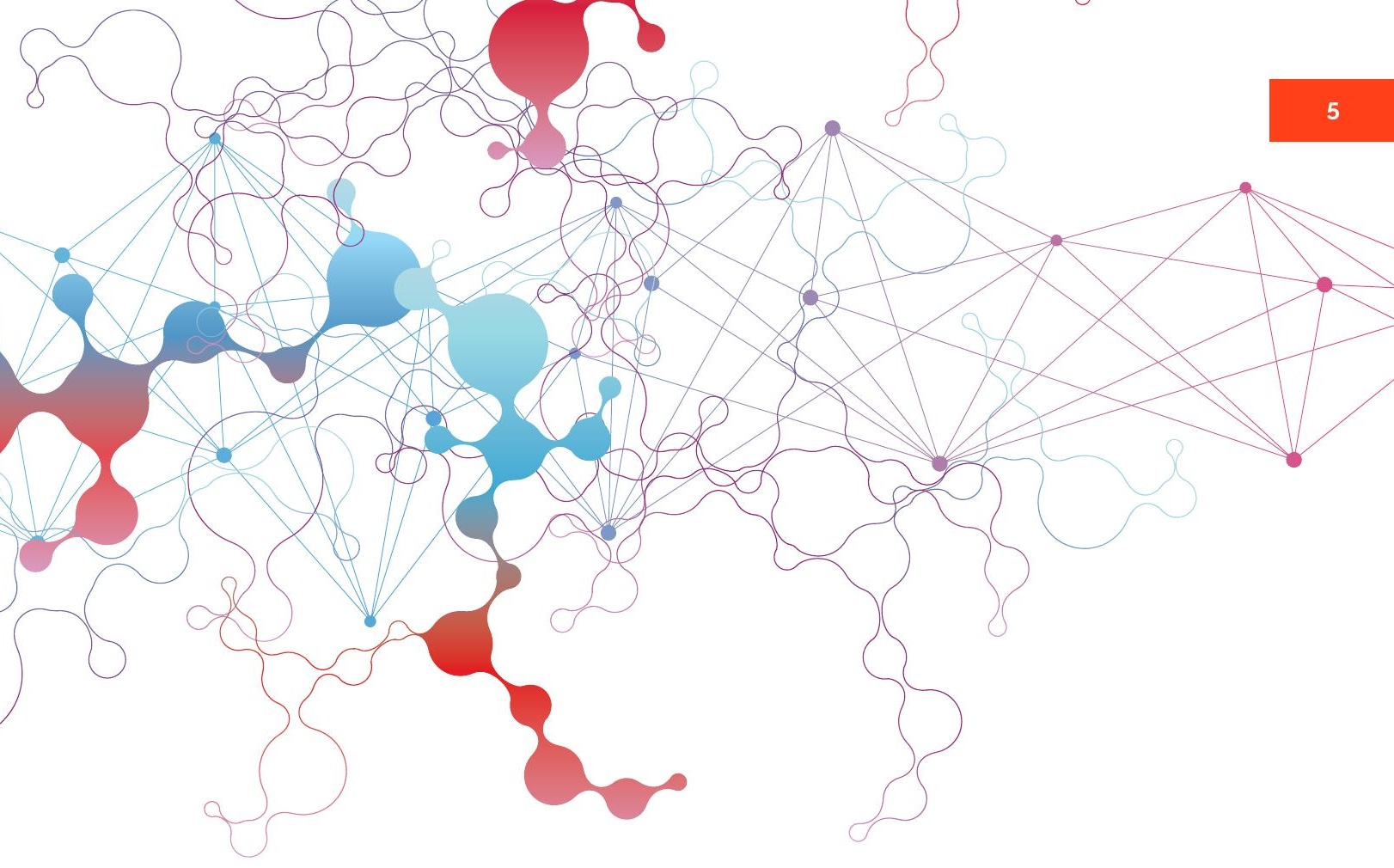

\section{Report for the Community of Latin American and Caribbean States (CELAC)}

On 26 March 2020, the Government of Mexico convened a virtual ministerial meeting on health affairs for response and follow-up to the COVID-19 pandemic in Latin America and the Caribbean, which was attended by foreign ministers and health representatives from 30 countries of the Community of Latin American and Caribbean States (CELAC), as well as regional organizations.

As a result of the meeting, CELAC formed a strategic alliance with the Economic Commission for Latin America and the Caribbean (ECLAC) and the Food and Agriculture Organization of the United Nations (FAO) to complement the regional strategy for the COVID-19 pandemic in Latin America and the Caribbean.

In response to the request made by CELAC, on 3 April ECLAC launched the COVID-19 Observatory in Latin America and the Caribbean: Economic and Social Impact, to continue providing support to track the spread of the virus in the medium and long terms, as well as the policy measures that countries are adopting to contain the pandemic and reduce its economic and social impacts.

As a regional public good, the Observatory generates and disseminates information to support evidence-based decision-making by governments, businesses, academic institutions and civil society organizations in the 33 countries of the Latin American and Caribbean region. 



\section{A. Before the pandemic, the region was already posting its lowest economic growth in decades and had limited fiscal policy space}

The COVID-19 pandemic impacted Latin America and the Caribbean at a time of economic weakness and macroeconomic vulnerability. In the decade following the global financial crisis (2010-2019), the rate of regional GDP growth declined from 6\% to 0.2\%; moreover, growth in the 2014-2019 period was the lowest level recorded since the 1950s (0.4\%) (see figure 1). As the pandemic spreads across the region, its nature as a health, economic and social crisis is increasingly evident. The extent and duration of its effects, although still too uncertain to quantify, are becoming clearer. It will result in the region's worst economic and social crisis in decades, with highly damaging effects on employment, the fight against poverty and the reduction of inequality. Quantifying the decline in economic activity enables authorities to determine the magnitude of the effort required for a return to normal. However, this return to normal will not and should not mean going back to the way things were before the pandemic. Medium-term considerations are also necessary to understand the structural changes in the organization of production that are already under way and are expected to gather pace. There will also be impacts -in some cases irreversible- on the labour structure, employment and well-being.

- Figure 1

Latin America and the Caribbean: real GDP growth, 1951-2019

(Percentages)

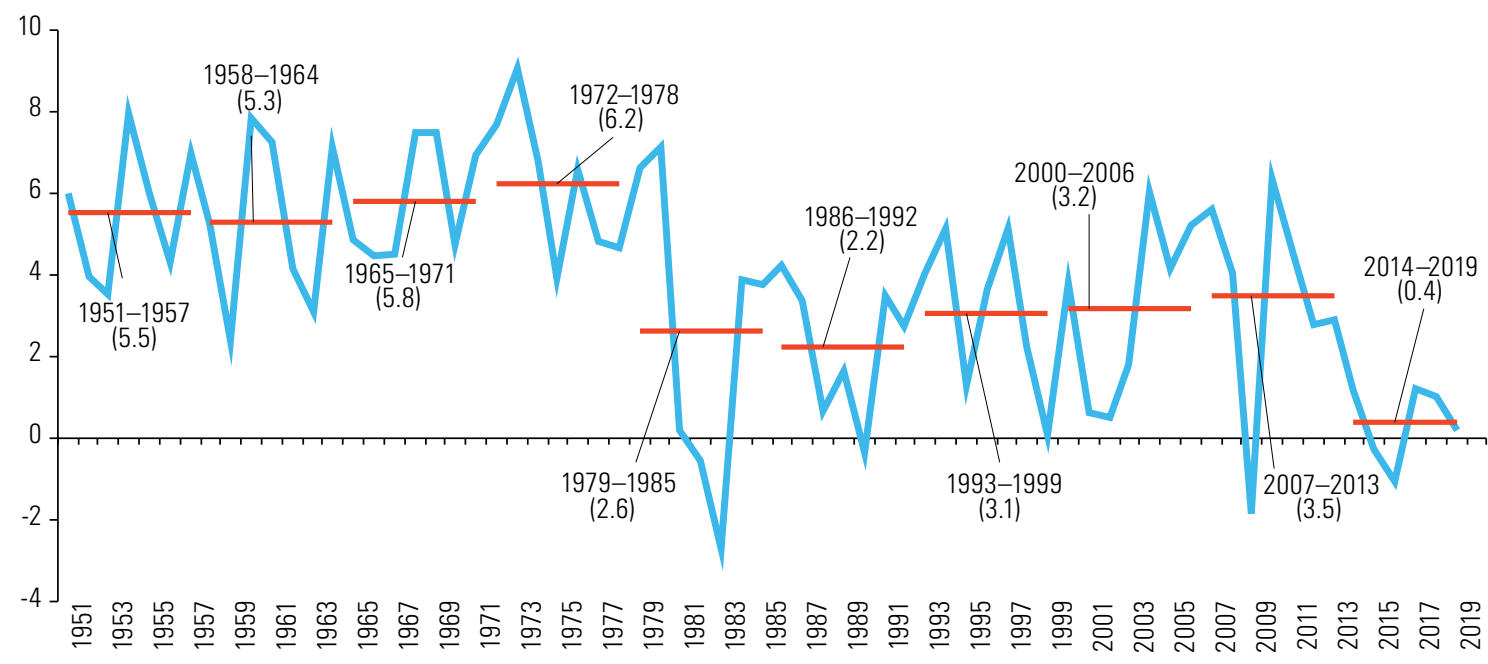

Source: Economic Commission for Latin America and the Caribbean (ECLAC), on the basis of official figures.

The accumulation of fiscal deficits in Latin America (2.7\% on average in the past decade) increased central governments' gross public debt, which in 2019 averaged $44.8 \%$ of GDP, an increase of 15 percentage points on the low registered in 2011. Debt levels were uneven from one country to another, from less than $25 \%$ of GDP at the end of 2019 in Paraguay and Peru to much higher figures in other countries: $89.4 \%$ in Argentina, $75.8 \%$ in Brazil and 61.3\% in Costa Rica. The weight of the debt is evident not just in central governments, but in non-financial public enterprises.

Higher interest payments have limited the resources available for development, as shown in the trend in health spending and investment. Interest payments climbed from 1.7\% of GDP in 2010 to $2.6 \%$ of GDP in 2019 (see figure 2), while health spending rose much less (from 1.9\% of GDP in 2010 to $2.3 \%$ in 2018). Meanwhile, capital spending declined from $3.9 \%$ of GDP to $3.2 \%$ of GDP, and acted as the variable of adjustment during the fiscal consolidation between 2016 and 2018. This situation is of particular concern in terms of the debt-service burden in Central American and Caribbean countries. 
- Figure 2

Latin America ( 16 countries): ${ }^{a}$ central governments' interest payments, capital spending and health spending, 2010-2019

(Percentages of GDP)

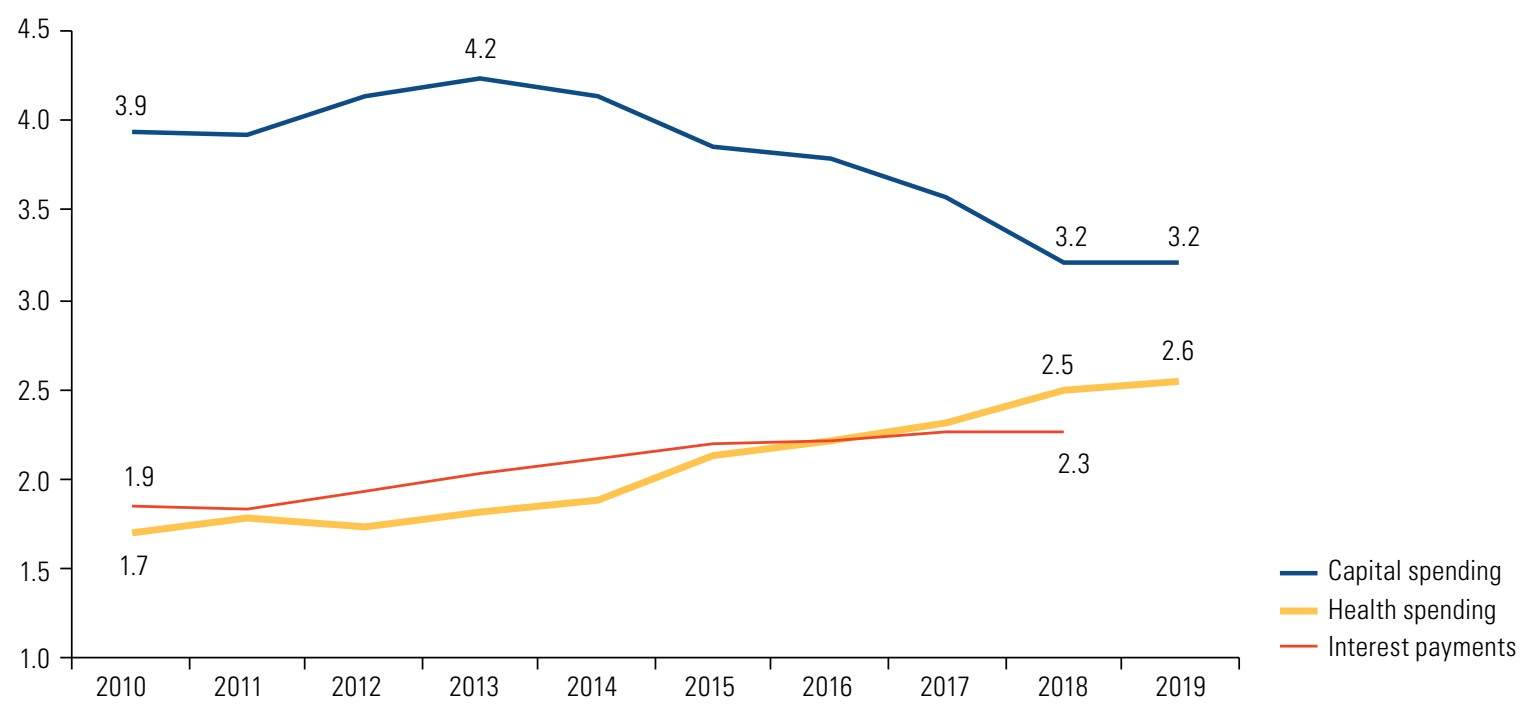

Source: Economic Commission for Latin America and the Caribbean (ECLAC), on the basis of official figures.

a Includes Argentina, Brazil, Chile, Colombia, Costa Rica, Dominican Republic, Ecuador, El Salvador, Guatemala, Honduras, Mexico, Nicaragua, Panama,

Paraguay, Peru and Uruguay.

b Health spending data available only up to 2018.

Although, over the past decade, the countries of Central America have sought to reduce their debt burden through fiscal reforms (Costa Rica, Honduras) or by generating primary surpluses (El Salvador), the public debt of the central governments increased from an average of $33.2 \%$ of GDP in 2010 to $44.0 \%$ of GDP in 2019. Meanwhile, interest payments rose from $1.8 \%$ of GDP to $2.5 \%$ of GDP. In pursuit of public debt sustainability, capital spending was reduced to offset the increase in interest payments, which exceed spending on areas such as health, education and social protection. For example, central government health spending by the Dominican Republic (1.7\% of GDP), El Salvador (2.4\% of GDP), Guatemala (1.1\% of GDP), Honduras ( $2.4 \%$ of GDP) and Panama (1.7\% of GDP) is lower than debt interest payments.

Most of the English-speaking countries of the Caribbean are shackled by high public debt because of their constant need for financing to repair production structure damage after climate-related disasters. Accordingly, interest payments are a heavy burden on public spending. Although central governments have achieved primary surpluses most years of the past decade (averaging $0.8 \%$ of GDP), they tend to run overall deficits, with an average of $2.5 \%$ of GDP. The need to generate primary surpluses hindered financing for public investment and social spending. Although the large primary surpluses resulted in a decrease in public debt from $72.8 \%$ of GDP in 2017 to $68.5 \%$ of GDP in 2019, countries such as Barbados, Belize and Jamaica still have high levels of debt and, therefore, high interest payments $(3.4 \%, 2.9 \%$ and $6.3 \%$ of GDP, respectively).

For Latin America and the Caribbean overall, fiscal space has also been reduced by limited public revenue. In the past decade, the central governments of Latin America recorded total public revenue accounting for $18.2 \%$ of GDP, on average. This stagnation stemmed from the slowdown in economic activity, tax evasion, the decline in international commodity prices -especially in South America and Mexico-, tariff reductions amid trade liberalization, and increasing tax revenue foregone through free zone and maquila concessions. In the current context, public revenue will be even more affected by the sharp contraction in economic activity and depressed commodity prices.

Amid this fiscal squeeze, four sets of problems related to social protection systems are heightening the effects of the pandemic. 
(i) High rates of informality, increased self-employment and gaps in access to contributory social protection.

(ii) Few countries have unemployment benefits; in 2019, only in eight Latin American and three Caribbean countries did formal sector workers have unemployment insurance.

(iii) Contributory social protection systems will be affected financially by higher demand for sick leave benefits by formal sector workers.

(iv) Tax-funded non-contributory social protection programmes that support the poorest will need to be extended to other low-income families at risk of falling into poverty

The health crisis is creating conditions that accentuate gender violence and show up the unjust social organization of care in the region, where it is considered an externality rather than a fundamental component of development. Children who cannot attend school require care that overburdens families' time, particularly that of women, who spend three times as long as men on unpaid domestic and care work each day. Moreover, gender inequalities are sharper in lower-income households, where the demands for care are greater, as they tend to have more dependants per household.

Women are also particularly affected by the pressure on health systems because they make up over $70 \%$ of the total number employed in the sector in the region. The greater demand has resulted in extreme working conditions, such as long working days without being able to rest or stop to eat or use the toilet, which increase health personnel's risk of being infected by the virus. Women working in the health sector are still responsible for dependants or people in need of care within their households. They must continue to go to work in addition to this responsibility, which increases their excess workload and stress.

\section{B. The pandemic will lead to the most severe contraction in economic activity in the region's history}

The pandemic is affecting the economies of Latin America and the Caribbean through external and domestic factors whose combined impact will lead to the most severe contraction that the region has experienced since records began in 1900.

The decline in the world's gross output in 2020 will be the largest in decades. Global GDP is expected to shrink by around $2 \%$, with a larger contraction in developed economies than in emerging economies. At the end of April, projections pointed to a decline of almost $4 \%$ for the United States (compared to a growth forecast of $1.9 \%$ in December 2019), less than $2 \%$ growth for China $(5.8 \%$ forecast in December), a decline of almost $6 \%$ for the eurozone $(1.2 \%$ growth forecast in December) and a contraction of more than $4 \%$ for Japan (see table 1).

- Table 1

Selected regions and countries: GDP growth rates for 2013-2019, and projections for 2020

(Percentages)

\begin{tabular}{|c|c|c|c|c|c|c|c|c|}
\hline & 2013 & 2014 & 2015 & 2016 & 2017 & 2018 & 2019 & 2020 \\
\hline World & 2.6 & 2.8 & 2.8 & 2.6 & 3.2 & 3.1 & 2.4 & -2.0 \\
\hline United States & 1.8 & 2.5 & 2.9 & 1.6 & 2.4 & 2.9 & 2.3 & -3.8 \\
\hline Japan & 2.0 & 0.4 & 1.3 & 0.6 & 2.0 & 0.8 & 0.7 & -4.2 \\
\hline Eurozone & -0.3 & 1.4 & 2.1 & 1.9 & 2.5 & 1.9 & 1.2 & -5.7 \\
\hline China & 7.8 & 7.3 & 6.9 & 6.7 & 6.9 & 6.6 & 6.1 & 1.8 \\
\hline India ${ }^{a}$ & 6.4 & 7.4 & 8.0 & 8.2 & 7.2 & 6.8 & 5.8 & 3.4 \\
\hline
\end{tabular}

Source: Economic Commission for Latin America and the Caribbean (ECLAC), on the basis of Institute of International Finance (IIF), Capital Flows Report: Sudden Stop in Emerging Markets, 9 April 2020; and data from Bloomberg.

a The figures for India refer to the fiscal year, which begins in April and ends in March the following year. 
The volume of world trade has fallen drastically: the World Trade Organization (WTO) (WTO, 2020) estimates a fall of between $13 \%$ and $32 \%$ in 2020 . The volume of global trade in goods was following a downtrend even before the pandemic. In 2019, it declined by $0.4 \%$, the first drop since the global financial crisis (see figure 3). This was largely the result of trade barriers built up since early 2018 (mainly between the United States and China) and their effect on global value chains. The outlook improved in January 2020 following the "phase one" agreement between China and the United States, but the pandemic put an end to that short-lived optimism. In addition to disruption of value chains, once China resumes production, it will have problems in exporting to countries that are experiencing the pandemic with a time lag with respect to its own timeline. Thus, one of the main players in world trade will see reduced demand for its exports, amplifying the negative impact on the global volume of trade.

\section{Figure 3}

Year-on-year change in the volume of global goods trade

(Percentages, on the basis of a seasonally adjusted index)

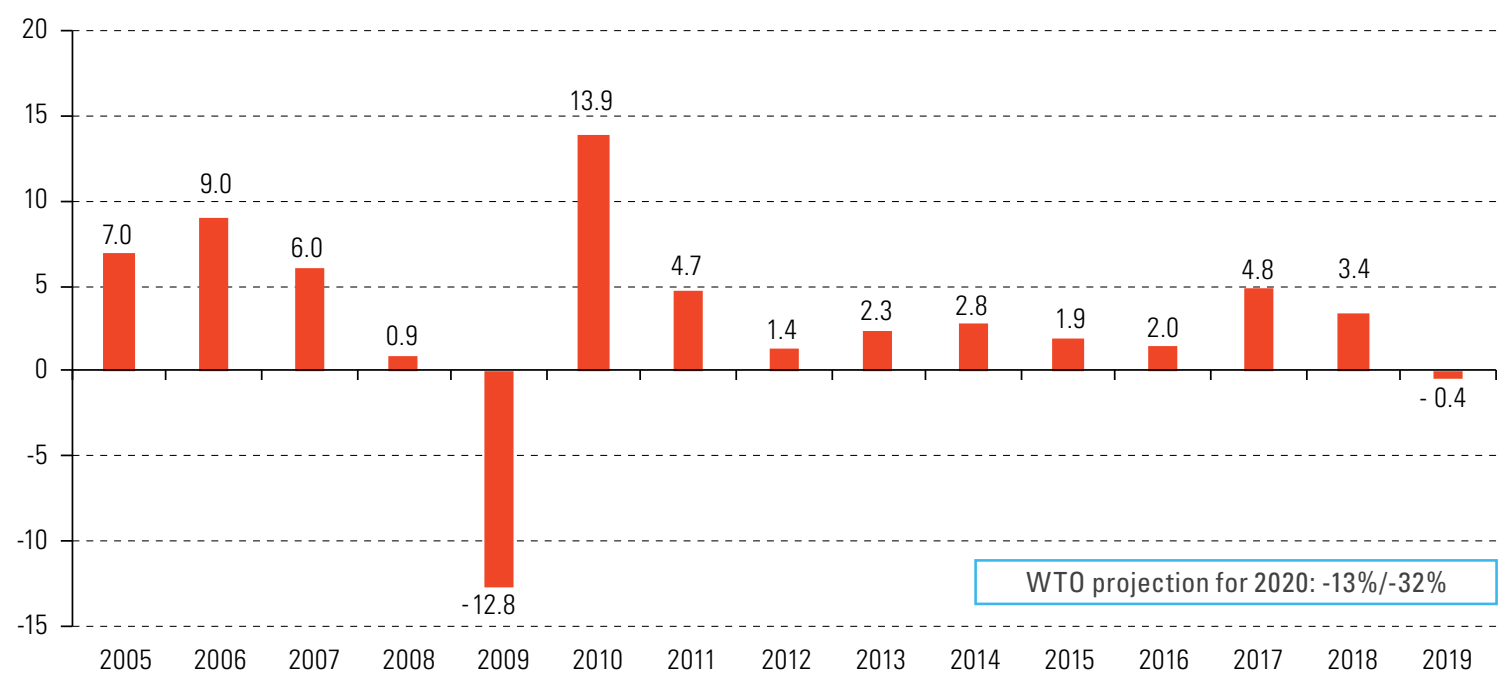

Source: Economic Commission for Latin America and the Caribbean (ECLAC), on the basis of Netherlands Bureau of Economic Policy Analysis (CPB), World Trade Monitor [online database] https://www.cpb.nl/en/worldtrademonitor. World Trade Organization (WTO), "Trade forecast press conference", 8 April 2020 [online] https://www.wto.org/english/news_e/spra_e/spra303_e.htm.

The drop in global economic activity, particularly in the United States, China and Europe, is hurting trade volumes and prices in Latin America and the Caribbean, especially for commodities. Some key production sectors in countries of the region form part of global value chains in which the United States and China are fundamental. In addition, Mexico and Central America are exposed to the contraction of the United States economy also through the reduction of migrant remittances; in the case of Mexico, this is compounded by the fall in oil prices. In view of the new economic outlook for the region's key trading partners and the steepening fall in export prices, the value of the region's exports could fall by nearly $15 \%$, with an $8.8 \%$ drop in prices and a $6 \%$ decline in volume, essentially owing to a sharper contraction in global demand (see table 2).

On average, the low prices are expected to persist, even for products that had not seen declines previously. For example, recently the market prices of agricultural products, which had not fallen as much as oil and metals, have begun to slide, due to shrinking demand. Soybean, corn and wheat prices have fallen by up to $4 \%$ and beef and chicken prices have dropped by $6 \%$. In the case of oil - the region's main export product - the sharp drop in demand, estimated at 30\%, was too large to be offset by the latest agreement of the Organization of Petroleum Exporting Countries (OPEC), which cuts the output of OPEC member countries by $20 \%$ (to 9.7 million barrels per day). 
- Table 2

Latin America and the Caribbean: impact of COVID-19 on exports of goods by subregion and major export country, projections for $2020^{a}$

(Percentage change)

\begin{tabular}{lccc} 
Region/Subregion/Country & Volume & Price & Value \\
\hline Latin America and the Caribbean & -6.0 & -8.8 & -14.8 \\
\hline Oil exporters & -4.7 & -14.6 & -19.2 \\
\hline Mineral exporters & -7.4 & -9.3 & -16.7 \\
\hline Exporters of agro-industrial products & -6.2 & -4.0 & -10.2 \\
\hline South America & -6.0 & -11.6 & -17.6 \\
\hline Brazil & -7.0 & -8.1 & -15.1 \\
\hline Mexico & -6.0 & -5.7 & -11.6 \\
\hline Central America & -4.9 & -5.3 & -10.3 \\
\hline Caribbean countries & -6.2 & -7.7 & -13.9
\end{tabular}

Source: Economic Commission for Latin America and the Caribbean (ECLAC).

a The following growth rates are assumed for 2020: -2.0\% (world), -3.8\% (United States), -4.2\% (Japan), -5.7\% (European Union, 27 countries), $1.8 \%$ (China) and $-5.3 \%$ (Latin America and the Caribbean), plus an average reduction of 18\% in the region's commodity export basket.

The greatest impact will be felt by the countries of South America, which specialize in the export of commodities and are therefore more vulnerable to a decline in their prices. The value of exports from Central America, the Caribbean and Mexico will be impacted by the slowdown in the United States economy. As mentioned above, Mexico will also experience a strong impact from the fall in oil prices. Regional exports to China are expected to fall the most in 2020 (24.4\%). This is likely to affect chiefly products with forward linkages in value chains in China (iron ore, copper ore, zinc, aluminium, soybeans, soybean oil, among others). The most exposed countries are Argentina, Brazil, Chile and Peru, the region's largest exporters of such products to China.

The deterioration in global financial conditions is as bad as in the 2008-2009 global financial crisis - and in some indicators worse.

Volatility has increased to record levels, there have been massive capital outflows from emerging markets, most currencies have depreciated against the dollar and there have been sharp increases in sovereign risk, except in countries that are considered safe havens to which investors "flee" in search of security, where sovereign risk has hit record lows. Stock markets around the world have plummeted, reflecting concerns about how the pandemic will affect companies' financials.

The fact that financial markets have been severely affected by the global pandemic is also a result of financial vulnerabilities that had been building up for a long time. The volume of debt has been growing faster than global income, and has reached all-time highs. In the fourth quarter of 2019, the global debt stock exceeded US\$ 255 trillion, more than $322 \%$ of global GDP (IFF, 2020a).

The increase in debt was accompanied by laxer borrowing requirements and greater appetite for risk among investors seeking higher returns. While debt has risen across all sectors (households, non-financial corporate sector, government and financial sector), what is extremely concerning now is that much of the debt accumulated since the global financial crisis has been incurred by the non-financial corporate sector, where disruption of supply chains and falls in global growth mean lower profitability and greater difficulty servicing debt. The recession makes it harder for corporate borrowers to make profits and repay debt and this is exacerbated by the rising costs of borrowing and the disruptions to access to financing.

In Latin America, the reduced availability of financing flows for emerging economies is translating into a slowdown in capital flows from abroad (a decrease of almost US $\$ 80$ billion compared to 2019) and net portfolio and other investment outflows among non-residents (IFF, 2020b). Remittance 
flows to Latin America and the Caribbean could contract by $10 \%-15 \%$ in 2020 and could take $4-8$ years to return to the levels seen in 2019. In several countries of the region, these flows make a very significant contribution to economic activity. In Haiti they represented more than $30 \%$ of GDP; in El Salvador and Honduras they contributed around 20\%, and in Guatemala, Jamaica and Nicaragua over $10 \%$. Between $80 \%$ and $90 \%$ of remittances are used to cover basic needs of recipient households (food, health and housing). The contraction will therefore have a major impact on consumption and on poverty.

In the main destination country for migrants from the region (the United States), the health crisis is affecting sectors where migrants are traditionally employed, such as construction, restaurants and hotels. In 2018, $28.7 \%$ of migrants from the countries of the region were employed in services and $20.6 \%$ in construction and maintenance (United States Bureau of the Census, 2018). The impact of the crisis on remittances could be mitigated by the direct support (transfers) received by migrants in destination countries and by recipient families in communities of origin. The crisis has also drawn attention to the contributions made by the immigrant workforce in sectors such as food production and health services in countries where migrants have a large presence.

Tourism is one of the worst affected sectors and its recovery will depend on how and when borders are opened across the world. Tourist arrivals globally are expected to fall by between $20 \%$ and $30 \%$ in 2020, a much larger drop than in 2009 (4\%) (UNWTO, 2020). In a scenario with a $30 \%$ drop in tourism revenues in 2020, GDP would fall by 2.5 in the Caribbean, 0.8 in Mexico and Central America, and 0.3 percentage points in South America. The knock-on effects on employment, household incomes and government revenues would be greatest in the Caribbean, where the sector employs some 2.4 million people and accounts for $15.5 \%$ of GDP. The effects of the decline in tourism will be felt in particular by micro- and small enterprises, which carry huge weight in the hotel and restaurant sector: accounting for $99 \%$ of enterprises and $77 \%$ of employment.

Major domestic impacts are adding to the external effects, as health policies to contain the spread of the pandemic bring production and economic activity to a halt. In the absence of treatments and vaccines for the virus, efforts to control the epidemic are focused on restricting people's movements, which affects production to different extents, depending on the sector. Quarantines and social isolation have led to heavy slumps in activities such as aviation, tourism, commerce and free zones. Companies, regardless of their size, are facing substantial falls in revenue, difficulties in obtaining credit and an increased likelihood of insolvency. In addition, severe impacts on people's working conditions and on employment or income are leading in turn to declines in countries' aggregate demand and increases in poverty.

\section{The Latin American and Caribbean economies in 2020: ECLAC projects a contraction of $5.3 \%$, adding almost 30 million to the number of poor}

In South America, the economy is expected to shrink by $5.2 \%$. Some countries in this subregion are badly affected by the downturn in China, the main market for their merchandise exports. This is true of Brazil, Chile, Peru and Uruguay, where more than $20 \%$ of exports (and more than $30 \%$ in Chile's case) go to China. This subregion will also be affected by falling commodity prices.

The disruption of value chains will have a more severe impact on the economies of Brazil and Mexico, which have the region's largest manufacturing sectors. Brazil's economy is expected to contract by $5.2 \%$ and Mexico's by $6.5 \%$. A less steep downturn $(-2.3 \%)$ is projected in the countries of Central America. As net importers of food and energy, they are less affected by lower commodity prices. However, they have been severely impacted by the decline in tourism and in activity in the United States, which is their main trading partner and largest source of foreign direct investment (FDI) and remittances. The Caribbean economies are expected to contract by $2.6 \%$, dragged down by lower demand for labour-intensive tourism services. 
- Table 3

Projected GDP growth rate for Latin America and the Caribbean, 2020

\begin{tabular}{|c|c|}
\hline & $\begin{array}{c}\text { GDP growth } \\
2020\end{array}$ \\
\hline Latin America and the Caribbean & $-5.3 \%$ \\
\hline Argentina & $-6.5 \%$ \\
\hline Bolivia (Plurinational State of) & $-3.0 \%$ \\
\hline Brazil & $-5.2 \%$ \\
\hline Chile & $-4.0 \%$ \\
\hline Colombia & $-2.6 \%$ \\
\hline Ecuador & $-6.5 \%$ \\
\hline Paraguay & $-1.5 \%$ \\
\hline Peru & $-4.0 \%$ \\
\hline Uruguay & $-4.0 \%$ \\
\hline Venezuela (Bolivarian Republic of) & $-18.0 \%$ \\
\hline South America & $-5.2 \%$ \\
\hline Costa Rica & $-3.6 \%$ \\
\hline Cuba & $-3.7 \%$ \\
\hline Dominican Republic & $0 \%$ \\
\hline EI Salvador & $-3.0 \%$ \\
\hline Guatemala & $-1.3 \%$ \\
\hline Haiti & $-3.1 \%$ \\
\hline Honduras & $-2.8 \%$ \\
\hline Mexico & $-6.5 \%$ \\
\hline Nicaragua & $-5.9 \%$ \\
\hline Panama & $-2.0 \%$ \\
\hline Central America and Mexico & $-5.5 \%$ \\
\hline Central America & $-2.3 \%$ \\
\hline Latin America & $-5.3 \%$ \\
\hline Antigua and Barbuda & $-7.2 \%$ \\
\hline Bahamas & $-6.8 \%$ \\
\hline Barbados & $-5.8 \%$ \\
\hline Belize & $-3.9 \%$ \\
\hline Dominica & $-3.6 \%$ \\
\hline Grenada & $-7.3 \%$ \\
\hline Guyana & $56.4 \%$ \\
\hline Jamaica & $-5.3 \%$ \\
\hline Saint Kitts and Nevis & $-6.5 \%$ \\
\hline Saint Lucia & $-8.1 \%$ \\
\hline Saint Vincent and the Grenadines & $-3.6 \%$ \\
\hline Suriname & $-4.4 \%$ \\
\hline Trinidad and Tobago & $-5.0 \%$ \\
\hline The Caribbean & $-2.5 \%$ \\
\hline
\end{tabular}

Source: Economic Commission for Latin America and the Caribbean (ECLAC).

Note: Central America includes Cuba, the Dominican Republic and Haiti.

Projections also point to a significant deterioration in labour indicators in 2020 . The unemployment rate is expected to climb to around 11.5\%, up 3.4 percentage points from the $8.1 \%$ recorded in 2019. This would bring the number of unemployed in the region to 37.7 million, an increase of nearly 11.6 million over the 2019 figure (26.1 million). These projections assume a fall of about $2.4 \%$ in the number of employed compared with 2019. In the Caribbean, where the tourism sector accounts for more than $50 \%$ of employment in many countries, the decline is likely to be sharper. These 
figures are significantly worse than those seen during the global financial crisis, when the region's unemployment rate rose from $6.7 \%$ in 2008 to $7.3 \%$ in 2009 (0.6 percentage points). The region's high rate of labour informality means that workers are extremely vulnerable to the effects of the pandemic and the measures to tackle it. The significant share of SMEs in job creation (accounting for more than $50 \%$ of formal employment) has amplified the adverse impacts on employment, as these firms have been badly hit by the crisis. Measures such as school closures and social distancing and the increase in the number of people falling ill will accentuate gender inequality by adding to the excessive burden of unpaid work performed by women.

Households will be directly affected by the 5.3\% contraction in GDP and the 3.4 percentage point increase in unemployment, with lower incomes and greater difficulty in procuring sufficient resources to meet basic needs. Against this backdrop, the poverty rate is expected to jump by 4.4 percentage points in 2020, from $30.3 \%$ to $34.7 \%$, which translates into a further 28.7 million in poverty (see table 4). Extreme poverty is expected to go up by 2.5 percentage points, from $11.0 \%$ to $13.5 \%$, which represents an increase of 16 million people.

Income distribution is also likely to worsen. Higher unemployment alone will raise the Gini coefficient by between $1 \%$ and $2 \%$, even before considering the additional rise in inequality stemming from the fall in employment income, which affects lower-income households more severely.

- Table 4

Latin America: poverty and extreme poverty in a scenario of a $5.3 \%$ drop in GDP and a 3.4 percentage point increase in unemployment in 2020

(Millions of people and percentages)

\begin{tabular}{lrcc} 
Year & $\mathbf{2 0 1 8}$ & $\mathbf{2 0 1 9}$ & $\mathbf{2 0 2 0 ^ { \circ }}$ \\
Population & 607.7 & 613.5 & 619.2 \\
\hline Poverty & & & \\
\hline Latin America (18 countries) & 180.6 & 186.0 & 214.7 \\
\hline Rate & $29.7 \%$ & $30.3 \%$ & $34.7 \%$ \\
\hline Extreme poverty & & & 83.4 \\
\hline Latin America (18 countries) & 62.5 & 67.5 & $13.5 \%$ \\
\hline Rate & $10.3 \%$ & $11.0 \%$ & \\
\hline
\end{tabular}

Source: Economic Commission for Latin America and the Caribbean (ECLAC).

a These estimates are preliminary and do not take into account the different impacts on certain production sectors or the employment created in each of those sectors. 



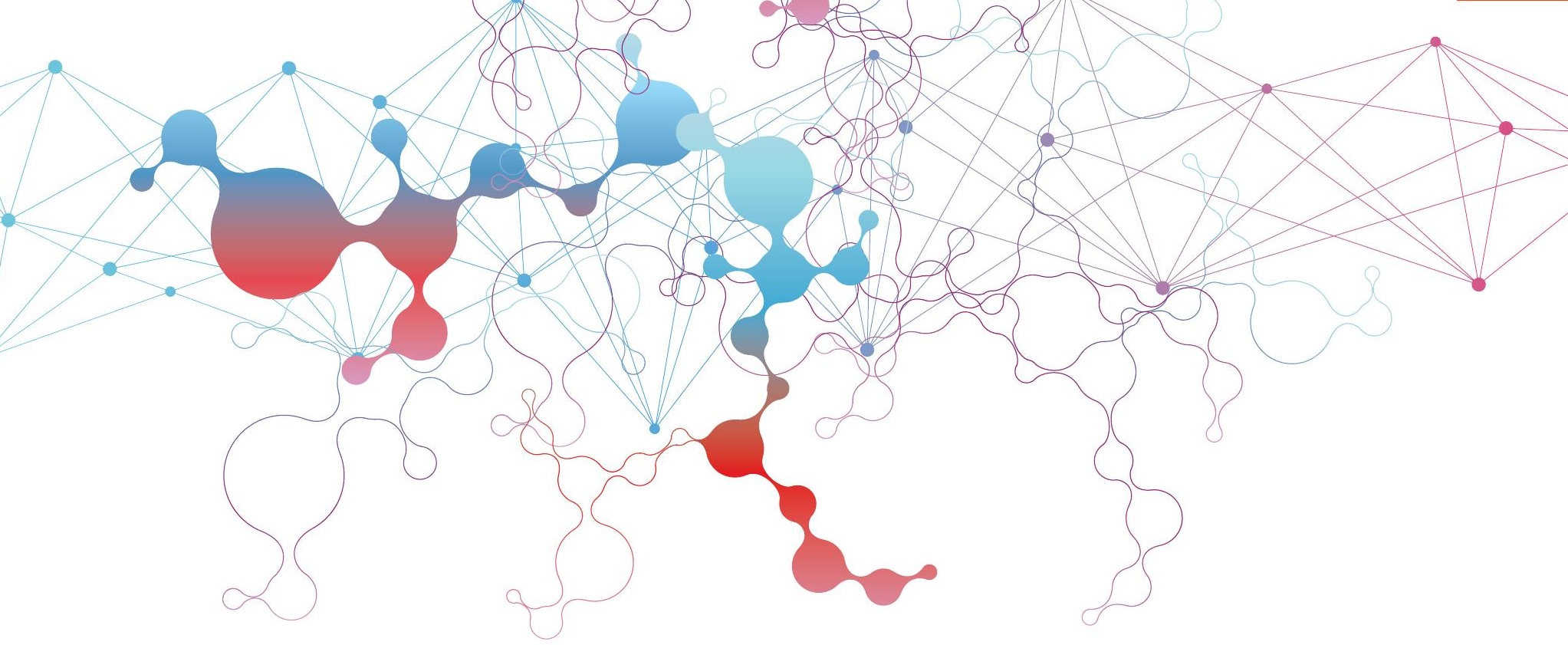

\section{Action taken by ECLAC}

ECLAC is committed to working with the countries of the region in this unprecedented crisis and has strengthened and refocused its work plan. The outcomes of this effort thus far are outlined below. We hope that the instruments and analyses produced will be useful for the exchange of experiences and, above all, for evidence-based decision-making in the ECLAC member States.

\section{A. COVID-19 Observatory in Latin America and the Caribbean: economic and social impact}

The COVID-19 Observatory in Latin America and the Caribbean: economic and social impact was launched on 3 April 2020, with the aim of providing a source of information and analysis on the economic and social impacts of the pandemic and monitoring the evolution of the crisis and the short-, medium- and long-term measures taken by the governments of the 33 countries of Latin America and the Caribbean. It is a regional communication platform for disseminating analyses of economic and social effects at the national and regional levels on the situation of health systems, the structure of the labour market, employment, education, industry, trade and macroeconomic policy. The Observatory is coordinated by ECLAC, with the support of the United Nations resident coordinators. ${ }^{2}$

A sign of the effectiveness of this initiative is that ECLAC appears as the first search result in Google under "COVID-19 Latin America and the Caribbean", and as the second for "COVID, Latin America and the Caribbean" (Spanish version). This visibility has resulted in the Commission's highest rate of click-through from Google in the past 12 months, positioning it as the go-to reference for the effects of COVID-19 in the region.

See [online] https://www.cepal.org/en/topics/covid-19. 


\section{COVID-19 geoportal: disseminating and monitoring actions to address the pandemic}

ECLAC has launched a geoportal, as part of the COVID-19 Observatory in Latin America and the Caribbean, which provides access to information on the actions taken by the countries of the region to address the pandemic. This information is disaggregated by type of measure: movement restrictions, health, the economy, work, social protection and education; gender-related actions will be included soon. This tool facilitates the dissemination and exchange of experiences within the region to enable countries to strengthen their management of the pandemic. Images 1, 2 and 3 show examples of the results provided by the portal.

The geoportal gives the date on which actions and measures were implemented, along with the respective details and the government organization responsible. The data flow begins in the each country with the collection of information on the measures and actions announced by the government. Once received at ECLAC headquarters, the data are compiled in a central database, complemented with data from the Commission's permanent databases and uploaded to the geoportal. Efforts are made to continuously improve the functionalities and automate the processes in the administration of this tool.

\section{- Image 1}

COVID-19 geoportal

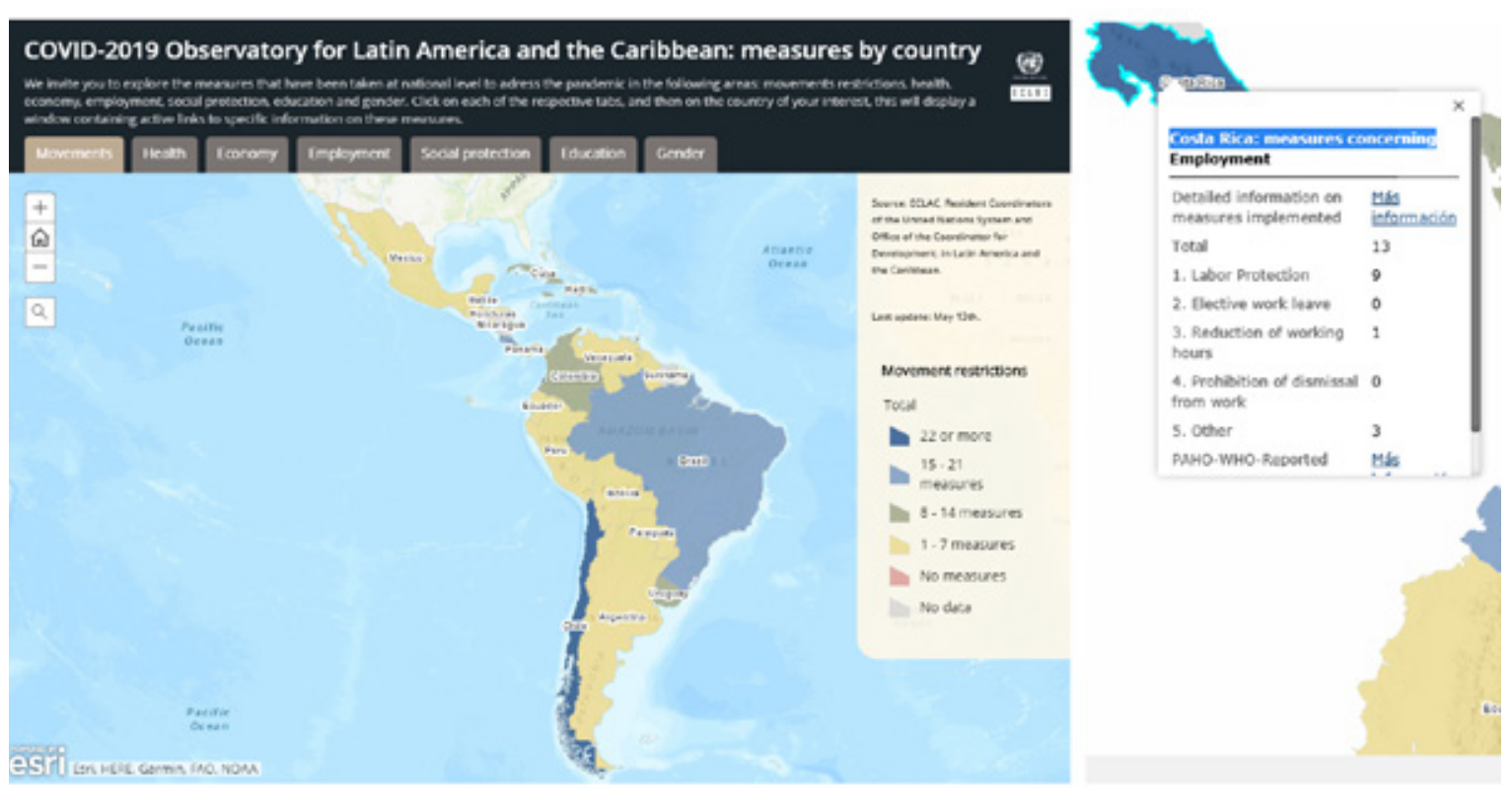

Source: Economic Commission for Latin America and the Caribbean (ECLAC), COVID-19 Observatory in Latin America and the Caribbean: Economic and Social Impact [online] https://www.cepal.org/en/topics/covid-19. 
- Image 2

Latin America and the Caribbean ( 31 countries): number of measures taken by governments each week to limit the impact of the pandemic, at 22 April 2020

\begin{tabular}{|c|c|c|c|c|c|c|c|c|c|c|c|c|c|c|c|c|c|c|}
\hline & 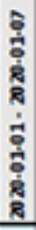 & 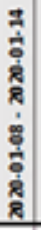 & 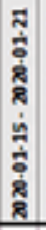 & 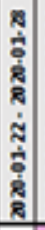 & 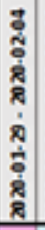 & 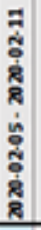 & 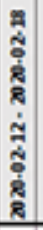 & 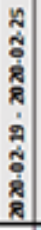 & 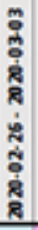 & 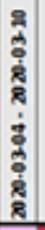 & 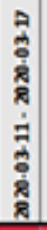 & 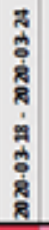 & 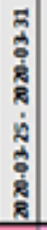 & 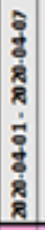 & 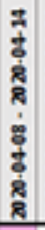 & 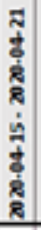 & 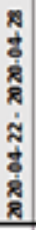 & 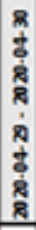 \\
\hline A. Movement restrictions & 1 & & & & 7 & 1 & & & 1 & 6 & 36 & 76 & 27 & 12 & 7 & & & \\
\hline 1. Restriction or ban on entry of foreign travellers & & & & & 2 & 1 & & & & 2 & 22 & 17 & 5 & 1 & & & & \\
\hline 2. Border closures and controls & 2 & & & & 4 & & & & 1 & 2 & 22 & 19 & 1 & 1 & & & & \\
\hline 3. Border controls & & & & & 1 & & & & & & 17 & 6 & 2 & & 1 & & & \\
\hline 4. Restriction or closure of public places and mass gatherings & & & & & & & & & & 3 & 23 & 29 & 15 & 7 & 2 & & & \\
\hline 5. Other movement between and within countries & & & & & & & & & & & 2 & 5 & 4 & 3 & 4 & & & \\
\hline B. Health & & & 1 & 3 & 6 & 3 & 1 & 3 & 5 & 5 & 72 & 68 & 24 & 18 & 10 & & & \\
\hline 1. Health emergency & & & 1 & 3 & 1 & 1 & & & 4 & 1 & 17 & 9 & 2 & 1 & 1 & & & \\
\hline 2. Mandatory coverage & & & & & & & & & & & 4 & 3 & 1 & & & & & \\
\hline 3. Mandatory quarantine for foreign travellers, and confirmed or suspected cases & & & & & 2 & & & & & 1 & 21 & 9 & 1 & & & & & \\
\hline 4. Mandatory general quarantine & & & & & 1 & 1 & & & & & 10 & 19 & 7 & 2 & 2 & & & \\
\hline 5. Type of policy on testing & & & & & 2 & & & 3 & 1 & 2 & 6 & 12 & 3 & 2 & & & & \\
\hline 6. Free test coverage expansion & & & & & & & 2 & & & & 4 & 6 & 2 & 1 & & & & \\
\hline 7. Hospitals & & & & & & 2 & & & & & 5 & 5 & 2 & 7 & 3 & & & \\
\hline 8. Other health-related & & & & & & & & & & 1 & 5 & 6 & 6 & 6 & 4 & & & \\
\hline C. Economy & & & & & 1 & 1 & & & & 3 & 63 & 156 & 34 & 17 & 11 & & & \\
\hline 1. Fiscal policy & & & & & & & & & & 2 & 11 & 28 & 10 & 10 & 1 & & & \\
\hline 2. Monetary policy & & & & & & & & & & & 13 & 29 & 4 & 1 & 1 & & & \\
\hline 3. Business policy & & & & & 1 & & & & & & 11 & 46 & 11 & 5 & 3 & & & \\
\hline 4. Restriction on economic activity & & & & & & & & & & 1 & 11 & 22 & 4 & & & & & \\
\hline 5. Price and quantity controls & & & & & & & & & & & 7 & 10 & 1 & & 1 & & & \\
\hline 6. Economic stimulus & & & & & & & & & & & 3 & 5 & 1 & & 2 & & & \\
\hline 7. Regulation of the personal hygiene and cleaning products market & & & & & & 1 & & & & & 9 & 5 & 3 & 1 & & & & \\
\hline 8. Debt relief and suspension of credit payments & & & & & & & & & & & & 1 & & & 2 & & & \\
\hline 9. Other economy-related & & & & & & & & & & & 3 & 10 & & & 1 & & & \\
\hline D. Employment & & & & & & & 1 & & & 3 & 44 & 54 & 11 & 10 & 1 & & & 1 \\
\hline 1. Labour protection & & & & & & & 1 & & & 3 & 25 & 37 & 7 & 9 & 1 & & & \\
\hline 2. Paid leave & & & & & & & & & & & 5 & 1 & & 1 & & & & \\
\hline 3. Reduction in working hours & & & & & & & & & & & 6 & 7 & 1 & & & & & \\
\hline 4. Ban on dismissal & & & & & & & & & & & 3 & 4 & & & & & & 1 \\
\hline 5. Other employment-related & & & & & & & & & & & 5 & 5 & 3 & & & & & \\
\hline E. Social protection & & & & & 1 & & & & & & 15 & 17 & 10 & 9 & 6 & & & \\
\hline 1. Cash transfers & & & & & 1 & & & & & & 15 & 12 & 7 & 3 & 3 & & & \\
\hline 2. Food/in-kind transfers & & & & & & & & & & & & 1 & 2 & 1 & 1 & & & \\
\hline 3. Guarantee of basic services & & & & & & & & & & & & 4 & & 3 & 2 & & & \\
\hline 4. Other social-protection-related & & & & & & & & & & & & & 1 & 2 & & & & \\
\hline F. Education/schools & & & & & & & & & & 3 & 39 & 26 & 4 & 7 & & & & \\
\hline 1. Suspension of classes & & & & & & & & & & 2 & 23 & 10 & 3 & 3 & & & & \\
\hline 2. Provision of tools for distance learning & & & & & & & & & & 1 & 14. & 11 & & 1 & & & & \\
\hline 3. Maintenance of school meals programmes & & & & & & & & & & & & 2 & & 3 & & & & \\
\hline 4. Other education- or school-related & & & & & & & & & & & 2 & 3 & 1 & & & & & \\
\hline G. Other & & & & & & & & & & 3 & 1. & 4 & & 1 & & & & \\
\hline TOTAL & 1 & & 1 & 3 & 15 & 5 & 2 & 3 & 6 & 23 & 325 & 401 & 110 & 74 & 35 & & & 1 \\
\hline
\end{tabular}

Source: Economic Commission for Latin America and the Caribbean (ECLAC). 
- Image 3

Latin America and the Caribbean (31 countries): proportion of countries that have taken specific measures to limit the impact of the pandemic, at 22 April 2020

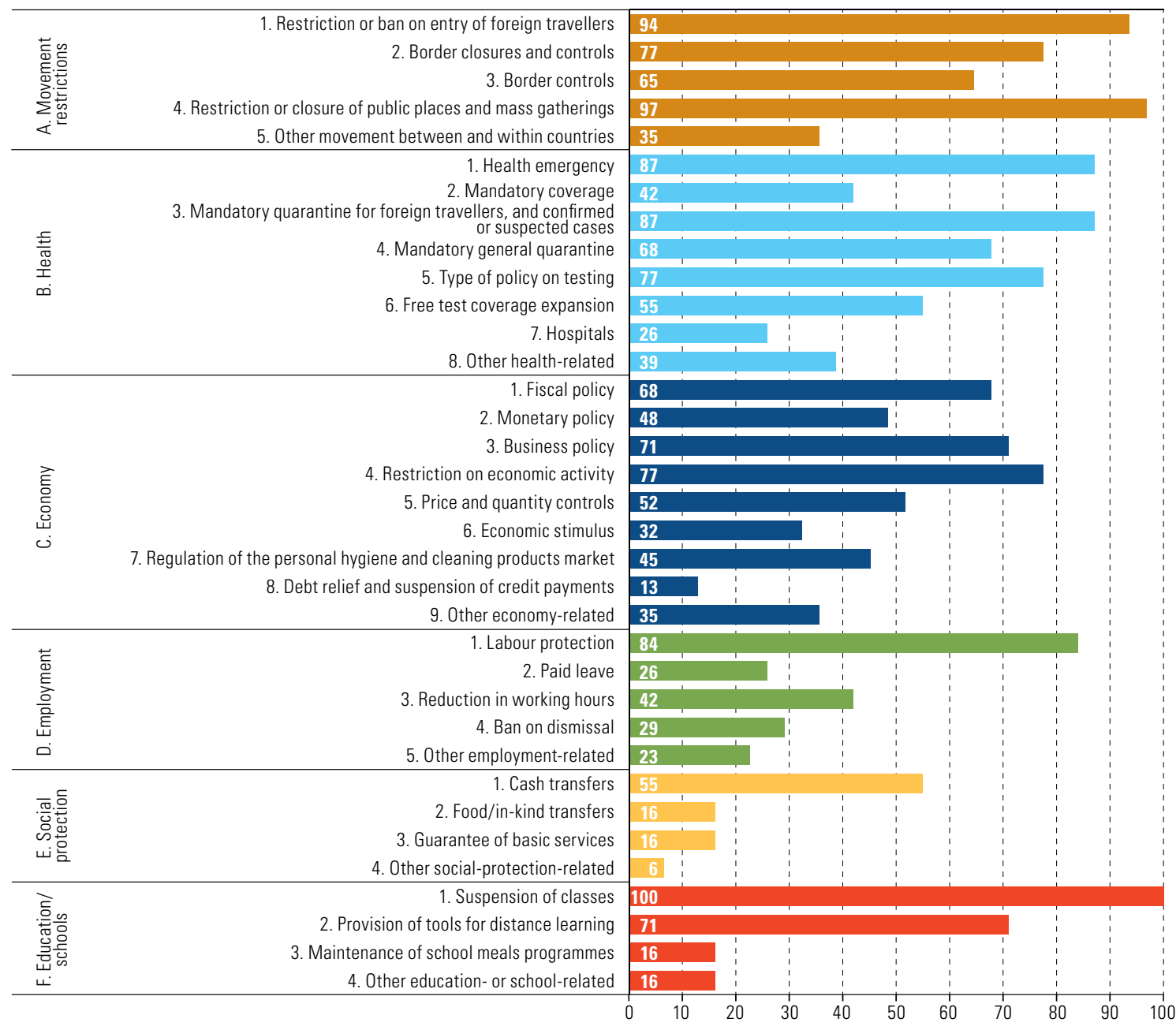

Source: Economic Commission for Latin America and the Caribbean (ECLAC).

\section{B. Knowledge Transfer Network of the Statistical Conference of the Americas: ideas and recommendations for the continuity of main statistical operations during the pandemic}

The Knowledge Transfer Network is a forum for strengthening knowledge and cooperation in the field of statistics in Latin America and the Caribbean. It supports the sharing of ideas and recommendations between national statistical offices (NSOs) and other actors in the national statistical systems, particularly on the continuity of main statistical operations during the pandemic (see image 4).

To this end, ECLAC, in collaboration with the International Labour Organization (ILO) and the National Institute of Statistics (INE) of Chile, which coordinates the Knowledge Transfer Network, has held videoconferences with the countries' statistical offices to address their concerns and provide technical assistance. The Network has a website dedicated to disseminating the publications and announcements of international organizations and NSOs concerning recommendations and contingency plans. ${ }^{3}$

3 See [online] https://rtc-cea.cepal.org/en. 
- Image 4

Example of a contingency plan and recommendations for statistical production in a health emergency

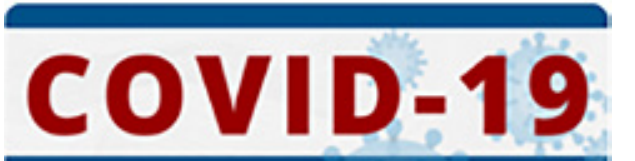

Planesdecontingencia Oficinas Nacionales de Estadística
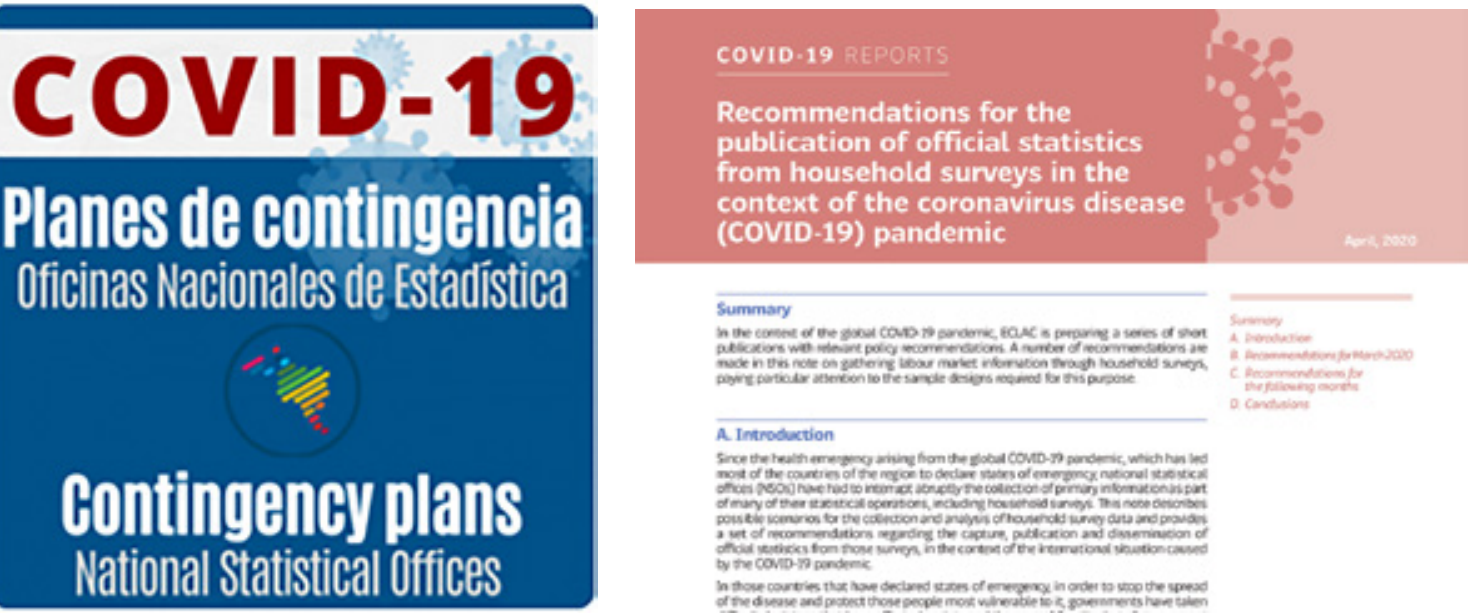

Source: Economic Commission for Latin America and the Caribbean (ECLAC), Knowledge Transfer Network of the Statistical Conference of the Americas [online] https://rtc-cea.cepal.org/en.

\section{Documents}

1. COVID-19 Special Report, No. 1, "Latin America and the Caribbean and the COVID-19 pandemic: economic and social effects", No. 2, "Measuring the impact of COVID-19 with a view to reactivation", and No. 3, "The social challenges in times of COVID-19"

These reports present information and analysis for policymakers and the general public on the socioeconomic impacts of the pandemic and provide elements for evidence-based policymaking in response to the crisis. The special reports are published periodically and address the impacts of the pandemic on specific areas (see image 5).

\section{- Image 5}

COVID-19 Special Reports, issues 1, 2 and 3

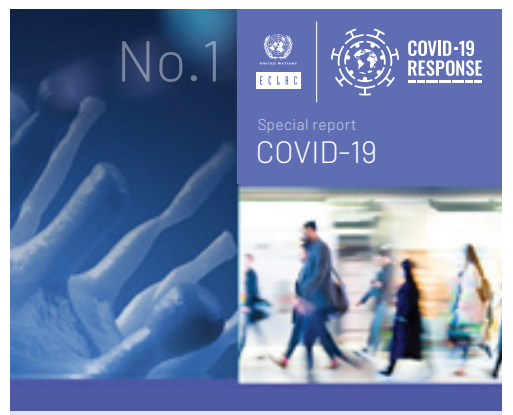

Latin America and the Caribbean and the COVID-19 pandemic Economic and social effects

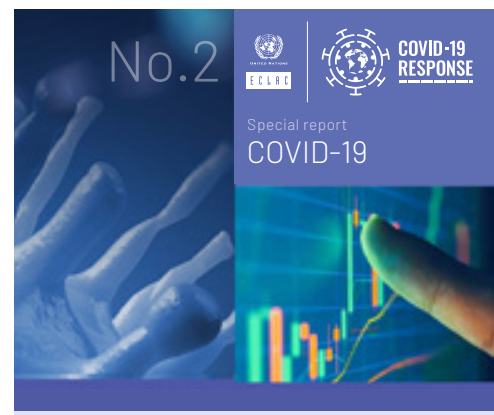

Measuring the impact of COVID-19 with a view to reactivation

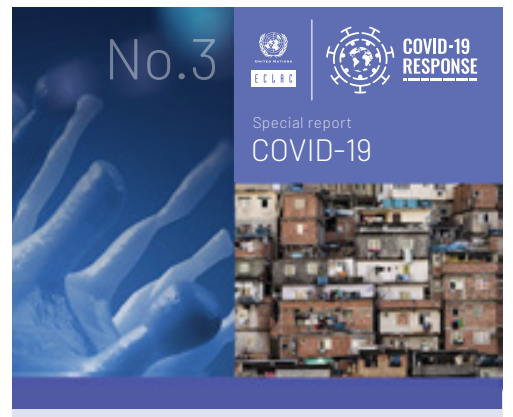

The social challenges in times of COVID-19

Source: Economic Commission for Latin America and the Caribbean (ECLAC) [online] https://repositorio.cepal.org/bitstream/handle/11362/45351/4/ S2000263_en.pdf and https://repositorio.cepal.org/bitstream/handle/11362/45477/4/S2000285_en.pdf. 
The first report looked at the transmission channels of the crisis in the economies of the region. The external channels studied included developments in international trade, commodity prices and remittances. The analysis of the domestic effects considered the impacts of the containment measures on different economic sectors and identified those most exposed to the interruption of activities.

Taking into account the potential channels of transmission and the sectoral structure of the economies, the second report presented estimates of how production, exports, employment, poverty and income distribution will vary, on the basis of information available as of 17 April 2020. The COVID-19 epidemic and its effects derived from external and domestic shocks to the economy have prompted a heavy downward revision of the projections given in December 2019 in the Preliminary Overview of the Economies of Latin America and the Caribbean, 2019 (ECLAC, 2019). As mentioned above, the region's GDP is now expected to fall by $5.3 \%$ on average, the worst contraction since those of 1930 and 1914.

The first issues of the report also analysed the policies implemented by the region's governments to address the social and economic effects of the pandemic, and the third issue set out a proposal to establish a universal basic income equivalent to one poverty line to cover the entire population living in poverty for six months. The reports have also touched on issues relating to the post-COVID-19 world and the fact that the crisis will bring about structural changes in the organization of production, international trade and the current model of globalization over the medium term.

To date, this is the only report of Latin American and Caribbean scope to offer scenarios regarding the evolution of GDP, exports, employment, poverty and income distribution. Future issues will analyse the impacts of the pandemic on food security, international trade in medical products and the use of digital technologies, among other topics.

Impacts of the first two issues of the special report as of 30 April:

- Special Report No. 2 has recorded over 20,000 downloads on the ECLAC website.

- Special Report No. 1 has recorded over 40,000 downloads. This is the highest number of downloads for a single publication since ECLAC began measuring this figure (this includes both the Spanish and English versions of the document).

\section{COVID-19: general recommendations for the care of older persons from a human rights perspective ${ }^{4}$}

This document focuses on care protocols for ensuring that the measures implemented protect the human rights of older persons. It served as the basis for the development of the protocol on care for older persons in Mexico City and was used in the recommendations made by the Office of the Ombusdperson of Peru to the country's Ministry of Development and Social Inclusion. It is being used as a reference by social organizations in Chile and Mexico, and as an input for the guidelines on the subject being developed by the Office of the United Nations High Commissioner for Human Rights (OHCHR). It has also been circulated by older persons' organizations in Europe and the by WHO in Geneva.

\section{The COVID-19 pandemic is exacerbating the care crisis in Latin America and the Caribbean ${ }^{5}$}

This document offers a diagnosis of the care crisis in Latin America and the Caribbean and highlights the relevance of the Santiago Commitment, in which the governments agreed to "Implement gender-sensitive countercyclical policies, in order to mitigate the impact of economic crises and 
recessions on women's lives and promote regulatory frameworks and policies to galvanize the economy in key sectors, including the care economy". The pandemic has brought to light as never before the importance of care for the sustainability of life and the unjust social organization of care in the region. It also shows up the limited visibility of care work in the economies of the region, where it is often treated as an externality instead of a fundamental component of development. There is an urgent need to develop responses to care needs from a gender perspective, since it is women who, whether paid or unpaid, perform the greatest share of these tasks.

\section{Impact of policies restricting international trade in medicines and medical supplies}

A study on the region's vulnerability vis-à-vis the restrictions imposed by more than 70 countries on the export of medicines and medical supplies essential for combating COVID-19. The messages of this report are: (i) Latin America and the Caribbean is almost totally dependent on imports of medical products from outside the region; (ii) export restrictions make it difficult to obtain essential supplies such as personal protective equipment and mechanical ventilators; (iii) the countries that have restricted their exports of these products include four of the region's five largest suppliers (the United States, the European Union, India and Switzerland), with China being the exception; (iv) the greatest source of vulnerability is the restrictions introduced by the United States, the region's top supplier of medical products; and ( $v$ ) the region must ramp up its productive capabilities in the pharmaceutical and medical supplies and device industries.

\section{Impacts on tourism}

A forthcoming study on the impact of the pandemic on tourism will describe its importance for the economies and for jobs in the countries in the region, review the effects of travel restrictions, analyse scenarios of the impact of the crisis on the sector's revenues, employment and GDP in 2020, and present the measures implemented and those proposed to mitigate the impacts and promote the reactivation of the sector.

\section{Virtual meetings}

In this period of over 40 days of teleworking, meetings have been held with government representatives at the highest level on matters relating to the plan of work, the work of the subsidiary bodies of ECLAC and the COVID-19 crisis. The participants in these meetings have included representatives of United Nations agencies, funds and programmes, as well as resident coordinators, as key actors in the implementation of actions in the field.

24. March-15 April Meeting of authorities of national statistical agencies. Through the Knowledge Transfer Network of the Statistical Conference of the Americas (Conectados RTC), six virtual meetings of national statistical offices and institutes were held, organized by ECLAC, with ILO and the National Institute of Statistics of Chile, to assist the countries of Latin America and the Caribbean in evaluating the impact of the pandemic on statistical operations. ECLAC reported on the results of a questionnaire sent previously to NSOs and central banks to ascertain the effects of the health emergency on the functioning of statistical institutions. Twenty countries responded to the survey and all reported being in a health emergency of some kind. The commitment of the NSOs and the standing of the Statistical Conference of the Americas of ECLAC facilitated this work at a distance. 
2 and 21 April A virtual meeting virtual meeting on the role of Social Development Ministries in Caribbean in the face of the COVID-19 pandemic was held in the framework of the Regional Conference on Social Development in Latin America and the Caribbean, with the participation of ministers and secretaries of social development. The meeting took place in two sessions: the representatives of the Latin American countries met on 2 April and those of the Caribbean countries on 21 April. Between them, the two meetings convened 29 representatives of member States and 10 representatives of associate members.

The meeting analysed the main socioeconomic problems and priorities in social protection; the difficulties and challenges of the crisis and lessons learned, and cooperation needs. All countries are taking measures to mitigate the impact of the crisis, principally by attempting to reduce the loss of human life, prevent poverty and extreme poverty from worsening, and avert setbacks in the protection of rights. They are aiming to sustain family incomes by means of resources in cash or in-kind (e.g. food assistance). All emphasized the impact of the crisis on the poor and the use of extraordinary conditional transfers to alleviate the lack of autonomous income amid the paralysis of economic activity, which has affected self-employed in particular.

Measures have been taken in conjunction with other government departments (economy, finance, health, education) and mechanisms have been set up with other sectors to provide governments with dialogue and technical support (round tables involving universities, medical schools, the private sector and others). The greatest difficulties are: (i) the limitations of population information and registration systems, particularly for groups who fall outside the target population traditionally served by ministries of social development, and the informal sectors, and (ii) how to get services to the most vulnerable owing to limited financial inclusion and operational difficulties at times of physical isolation and restriction on movements by the population. It was stressed that the urgency of the immediate situation should not be allowed to prevent looking towards the future in relation to long-term challenges. ${ }^{6}$

8 April Technical meeting on challenges and needs of the ministries of social development vis-à-vis the COVID-19 pandemic. The purpose of the meeting was to share lessons learned, exchange experiences and identify areas of mutual technical assistance and international cooperation on urgent issues and aspects identified by governments regarding care of the population in the pandemic. The difficulties and challenges highlighted revolved around the management and quality of data sources, particularly for selecting and accessing the target population. The representatives emphasized the usefulness of measures based on digital technologies and innovative management models, as well as the importance of maintaining a medium- and long-term view while responding to the emergency. The representatives also commended the inter-agency work and work carried out with United Nations agencies, funds and programmes.

8 April Briefing of Ministers and high-level authorities of machineries for the advancement of women in Latin America and the Caribbean: The response to the COVID-19 pandemic crisis from a gender perspective. Organized by ECLAC and the United Nations Entity for Gender Equality and the Empowerment of Women (UN-Women); convening representatives from 29 countries in the region. ECLAC presented the document The COVID-19 pandemic is exacerbating the care crisis in Latin America and the Caribbean ${ }^{7}$ and a mapping of initiatives by Latin American and Caribbean governments to address the gender dimensions of the COVID-19 pandemic. ${ }^{8}$

The central themes of the meeting were the accentuation of the unequal distribution of care tasks in the context of social isolation, and the increase in situations of physical, psychological and economic violence against women caused by staying at home. The importance of the Montevideo Strategy for Implementation of the Regional Gender Agenda within the Sustainable Development

6 See ECLAC, "Alicia Bárcena calls for implementing universal, redistributive and solidarity-based policies to avoid another lost decade" [online] https://www.cepal.org/en/news/alicia-barcena-calls-implementing-universal-redistributive-and-solidarity-based-policies-avoid, and "Alicia Bárcena encouraged Caribbean countries to advance towards less unequal and more caring societies, leaving no one behind [online] https://www.cepal. org/en/news/alicia-barcena-encouraged-caribbean-countries-advance-towards-less-unequal-and-more-caring.

See ECLAC (2020d).

8 Spanish only. See [online] https://data2.unhcr.org/en/documents/download/75750. 
Framework by 2030 and the Santiago Commitment was emphasized, as regional instruments for a comprehensive approach to pandemic responses. Information was shared on the main initiatives in areas such as the prevention of violence against women, the promotion of co-responsibility for care, and the protection of women's jobs and income. As a result, ECLAC is including government initiatives on gender equality in the COVID-19 Observatory and will continue to promote opportunities for discussion and regional cooperation to foster a gender-sensitive, coordinated response to the crisis. ${ }^{9}$

13 April Virtual meeting of Ministers of Finance of Latin America and the Caribbean to share experiences on fiscal responses to the crisis generated by the COVID-19 pandemic. The presentations referred to common objectives in strategies to control the pandemic and mitigate its social and economic effects. Among the measures implemented are: increases in public health system budgets to expand their capacity to provide care; the strengthening of social protection networks with transfers to compensate for the income losses of formal and informal workers; credit lines to provide liquidity to businesses, especially small and medium-sized enterprises (SMEs), to protect the economy's productive capacity, and tax relief measures to provide short-term liquidity to taxpayers. The countries agreed on the importance of holding additional virtual meetings to continue sharing information and fostering regional discussion on initiatives to address shared fiscal issues.

The chapter of this meeting corresponding to the Caribbean countries, both member and associate member countries, is now being organized. The Caribbean economies are particularly affected by the fall in trade with the United States, their dependence on imported products and the total loss of income due to the shutdown of tourism.

21 April Virtual Latin America Meeting: Impact on the region's maritime industry during the global crisis of COVID-19, organized jointly with the Women's International Shipping \& Trading Association (WISTA) and the Latin American Network of Women in Maritime Authorities (Red MAMLa). Representatives participated from Argentina, the Bolivarian Republic of Venezuela, Chile, Colombia, Mexico, Panama, Peru and Uruguay.

23 April Challenges in the Colombian port sector, a meeting organized with the National Business Association (ANDI) and the National Infrastructure Agency (ANI) of Colombia.

\section{E. Meetings scheduled}

Virtual meeting with ministers and authorities of planning of Latin America and the Caribbean. A meeting of planning authorities is being organized jointly with the Office of Planning and the Budget (OPP) of Uruguay, in its capacity as Chair of the Regional Council for Planning, to analyse the impact of the COVID-19 crisis on planning, territory and budgets. The meeting is expected to take place in May.

Meeting of authorities on ageing and older persons in Latin America and the Caribbean. This meeting is being organized jointly with Paraguay, as Chair of the Fourth Regional Intergovernmental Conference on Ageing and the Rights of Older Persons in Latin America and the Caribbean, with the purpose of analysing the impacts of COVID-19 on older persons.

Meeting of civil society organizations of Latin America and the Caribbean. A meeting with civil society participants from the region is being organized with the International Centre for Strategic Thinking (CEPEI) to review civil society activities in the context of the pandemic. This event is expected to convene a broad range of stakeholders based on the network of civil society organizations participating in the Forum of the Countries of Latin America and the Caribbean on Sustainable Development and the Mechanism for civil society participation in the Sustainable Development Agenda.

9 See ECLAC, "In light of women's greater exposure, ECLAC calls on States to guarantee their rights in the context of the COVID-19 pandemic" [online] https://www.cepal.org/en/pressreleases/light-womens-greater-exposure-eclac-calls-states-guarantee-their-rights-context-covid. 


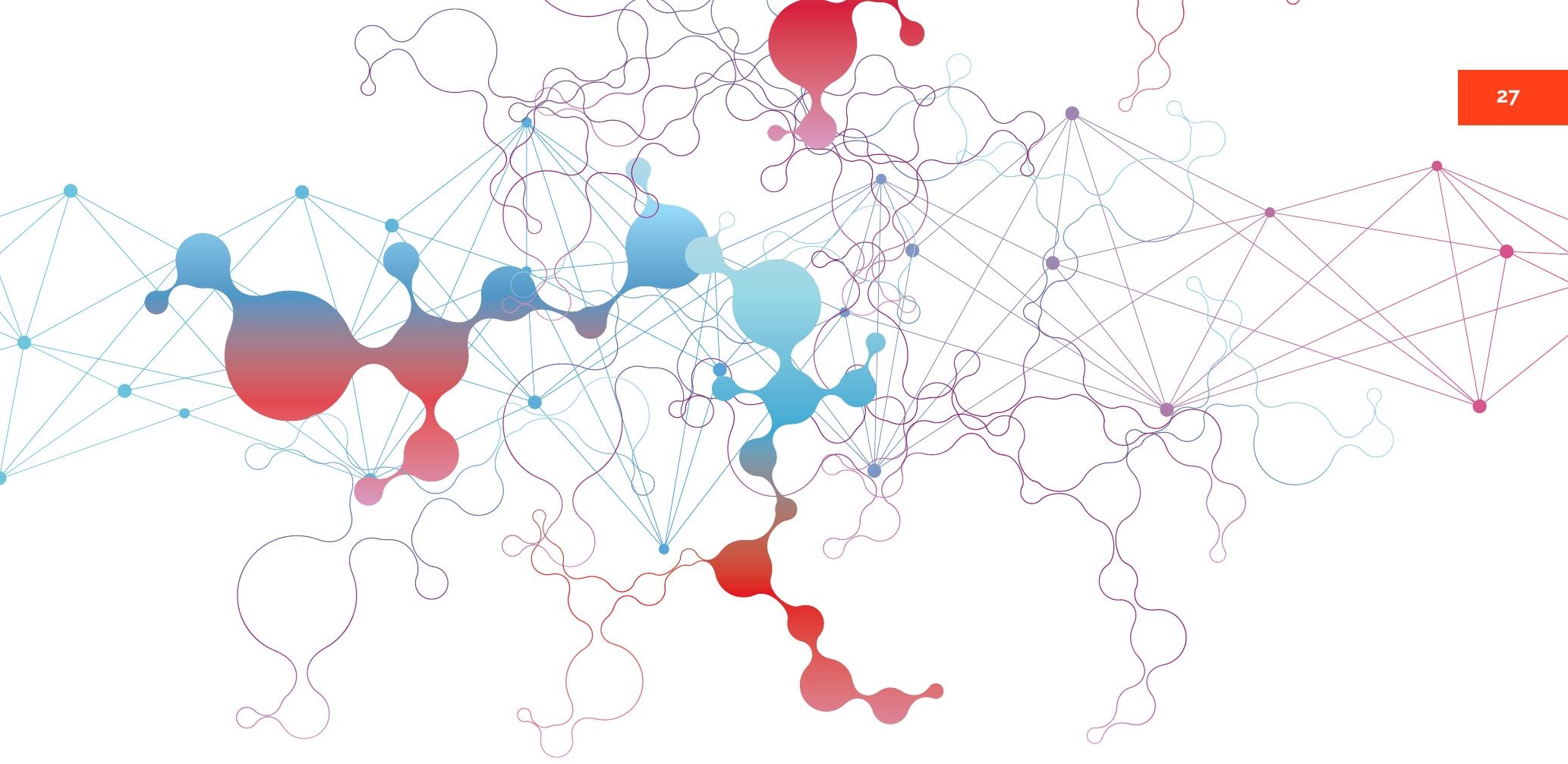

\section{Policies to tackle the economic and social effects of the pandemic}

\section{A. Initial responses}

The countries of Latin America and the Caribbean were quick to implement significant measures in response to the initial stage of the crisis, adopting broad packages of economic policies to mitigate its social and economic effects (see table 5). These measures aim to increase public resources for the health sector, protect households (especially the most vulnerable ones), safeguard production capacity and employment, stave off a liquidity crisis and prevent the collapse of the economic system.

The scale of the fiscal policy effort exceeds even those deployed during the global financial crisis. Countries have taken steps to release resources quickly through widespread budget reallocations to strengthen health systems and expand social safety nets by means of transfers to offset income losses of formal-sector and informal employees. These initiatives have often been accompanied by tax relief measures aimed at reducing pressure on companies' cash flows. In addition, credit guarantees have been extended to ensure that companies, especially SMEs, have access to liquidity provided that they maintain employment levels.

Monetary authorities have taken measures to increase liquidity through the use of traditional instruments and have lowered monetary policy interest rates and legal reserve requirements. They have announced assistance to financial institutions, especially through short-term markets, to avoid mismatches and prevent illiquidity from turning into insolvency. Interventions on the foreign-exchange market have also been stepped up, not to reverse currency depreciations that have already occurred, but to mitigate volatility. 
- Table 5

Policy measures in response to the COVID-19 pandemic

The region's countries have taken immediate measures to contain the virus and protect the workforce and household income

- Travel restrictions and monitoring of travellers from areas affected by COVID-19.

- Flight bans (to and from specific countries) and border closures.

- Distance learning and homeschooling (with asymmetries in connectivity).

- Social distancing, with the closure of restaurants, bars, cinemas, the encouragement of teleworking and reduced office hours.

- Strengthening health sector capacity: health infrastructure (beds, mobile hospitals, medical supplies) across the region is fragmented and insufficient, counting just over 2 beds per 1000 people.

- Total or partial quarantine with working arrangements including legal measures for teleworking, reduced working hours, introduction of flexible hours, advance leave and protection against dismissal.

- Protection of the workforce and income in the form of wage support to offset loss of income through advance payments, wage subsidies, strengthening of unemployment insurance and the suspension or reduction of payments for water, gas and electricity services or towards private pension funds.

- Social protection to reduce the social impact on people with the lowest incomes through subsidies, cash transfers or advance payments, social programmes and social protection mechanisms.

- Special financial support for SMEs and other companies and the informal sector, by renegotiating and improving conditions for bank loans.

\section{Monetary, fiscal and social measures to avoid the collapse of the economic system}

- Monetary and financial measures to preserve bank liquidity, support commerce and address public and private debt; lowering of central bank interest rates and opening of special credit lines, granting of additional loans, extension of repayment terms for consumer and corporate loans or extension of mortgage terms.

- Fiscal measures include flexibility to redirect public budgets, introduce tax relief measures, defer tax returns or apply tax exemptions for certain sectors; finance ministers should reorganize budgets and seek additional financing to channel resources towards urgent short-term measures. Argentina, the Bahamas, Barbados, Belize, Brazil, Chile, Colombia, Guatemala, Honduras, Jamaica, Paraguay, Peru, Trinidad and Tobago and Uruguay have implemented fiscal packages ranging from $0.6 \%$ of GDP to more than $10 \%$ of GDP when State loan guarantees are included.

- Measures to preserve production capacity and to create the conditions to revive economic activity through liquidity mechanisms for companies, particularly SMEs.

- Measures to expand social protection systems to cover underemployed or own-account workers, young people, women, children and older persons.

Source: Economic Commission for Latin America and the Caribbean (ECLAC).

The fiscal stimulus measures taken in response to the humanitarian and economic crisis will substantially widen fiscal deficits and increase debt levels in many countries. Therefore, fiscal covenants will have to be renewed in many countries of the region to enable them to face future adjustments and minimize financial risks.

Between 13 March and 24 April 2020, 29 countries in the region adopted 126 social protection measures to help households facing the greatest poverty, vulnerability and insecurity. In the second half of March, the number of countries and measures increased almost every day (see figure 4).

The main measures implemented have been the provision of food and the establishment of new cash transfers, which accounted for $33 \%$ and $27 \%$ of the measures adopted, respectively, followed by the suspension of payments for basic services (water, electricity, telephone and Internet) and increases in the amounts allocated under existing cash transfers (19\% and $13 \%$, respectively). Early disbursement of existing cash transfers accounts for $5 \%$ of measures adopted, while the expansion of population coverage of existing cash transfers represents $4 \%$ (see figure 5). Another important measure has been the lifting of conditionalities for a number of existing cash transfer programmes because families have been unable, for example, to send their children to school. 
- Figure 4

Latin America and the Caribbean (29 countries): ${ }^{a}$ social protection measures for the population living in poverty and vulnerability announced in response to the COVID-19 pandemic, 13 March-24 April 2020

(Number of measures, daily figures)

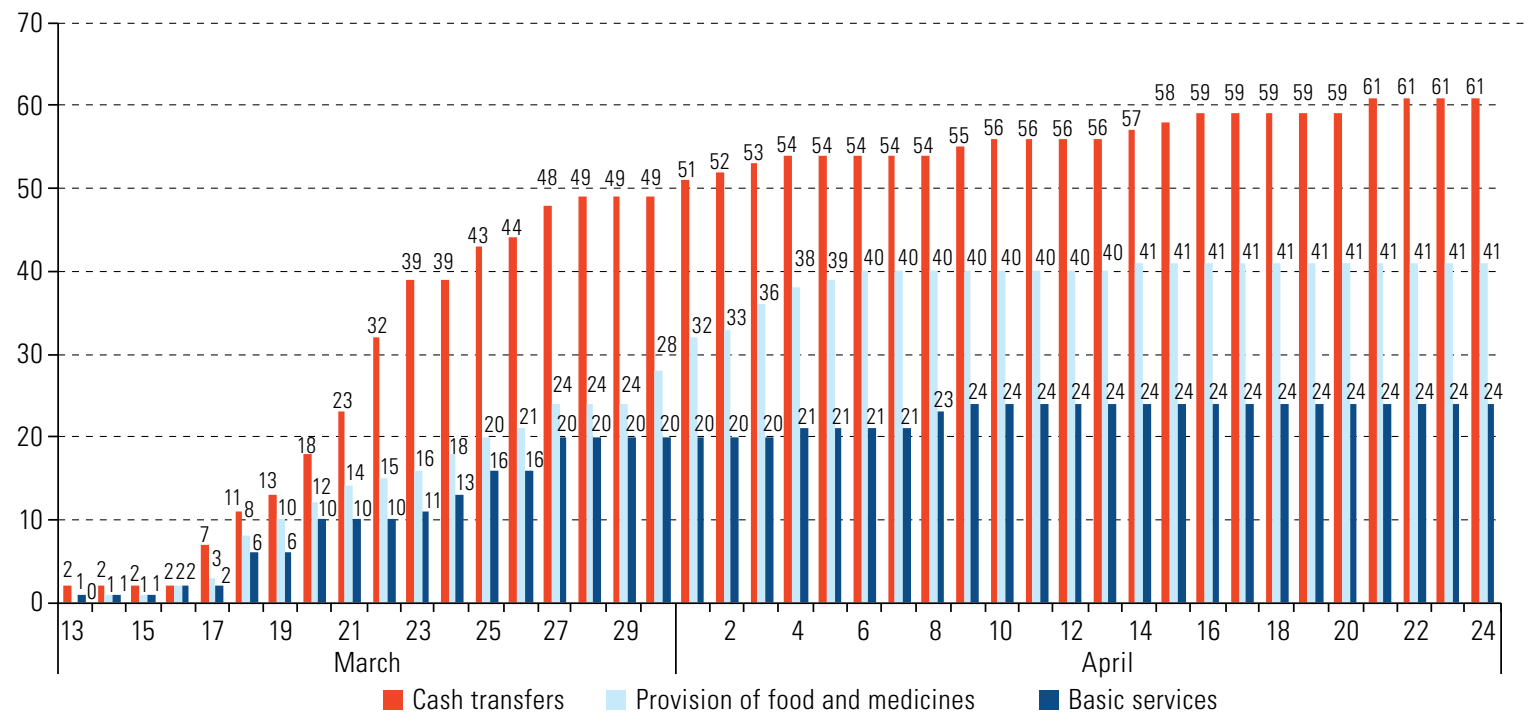

Source: Economic Commission for Latin America and the Caribbean (ECLAC).

a Antigua and Barbuda, Argentina, Bahamas, Barbados, Belize, Bolivarian Republic of Venezuela, Brazil, Chile, Colombia, Costa Rica, Cuba, Dominican Republic, Ecuador, El Salvador, Grenada, Guatemala, Guyana, Haiti, Honduras, Jamaica, Mexico, Panama, Paraguay, Peru, Plurinational State of Bolivia, Saint Lucia, Saint Vincent and the Grenadines, Trinidad and Tobago, and Uruguay.

\section{- Figure 5}

Latin America and the Caribbean ( 29 countries): ${ }^{a}$ social protection measures for the population living in poverty and vulnerability announced in response to the COVID-19 pandemic, by type of measure, at 24 April 2020

(Number of measures and percentage distribution)

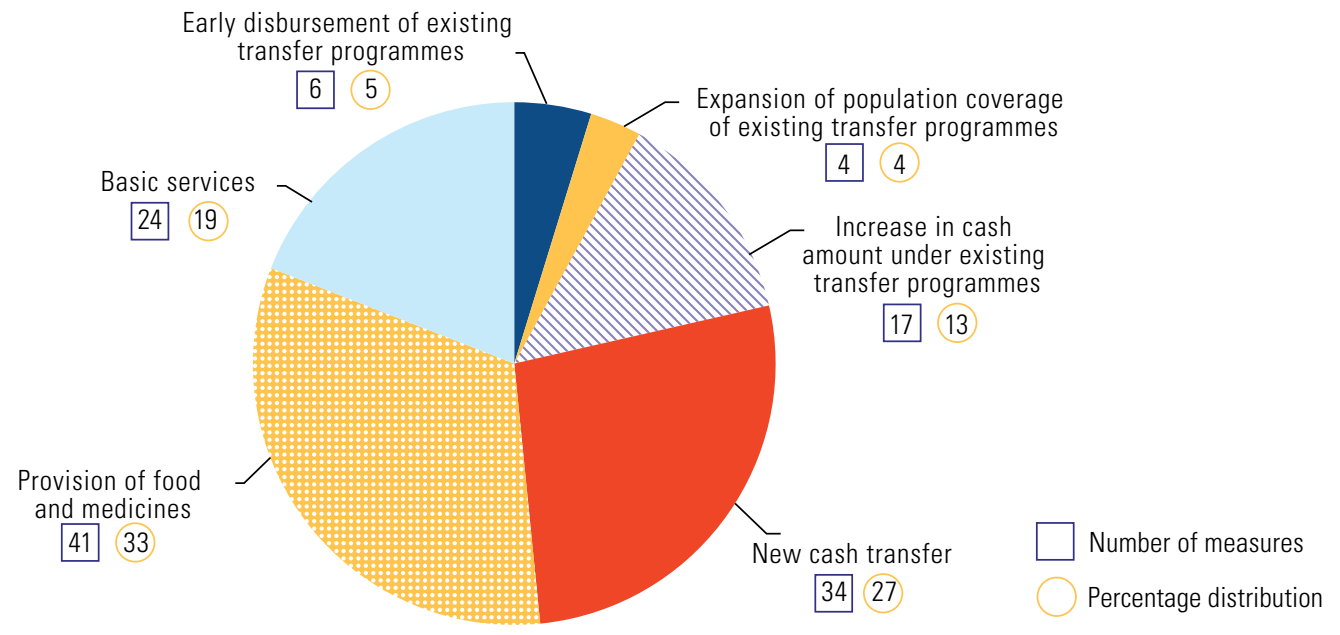

Source: Economic Commission for Latin America and the Caribbean (ECLAC).

a Antigua and Barbuda, Argentina, Bahamas, Barbados, Belize, Bolivarian Republic of Venezuela, Brazil, Chile, Colombia, Costa Rica, Cuba, Dominican Republic, Ecuador, El Salvador, Grenada, Guatemala, Guyana, Haiti, Honduras, Jamaica, Mexico, Panama, Paraguay, Peru, Plurinational State of Bolivia, Saint Lucia, Saint Vincent and the Grenadines, Trinidad and Tobago, and Uruguay. 


\section{B. Policies for further progress in mitigating the effects of the crisis}

The fiscal packages announced in the region were the first response to the socioeconomic impact of the pandemic. Additional efforts will be required as the magnitude of the crisis increases. This will require expanded fiscal space, which in turn will require access to financing on favourable terms.

An increasing number of countries in the region have requested emergency financing from international financial institutions such as the International Monetary Fund (IMF), the World Bank, the Inter-American Development Bank (IDB) and the Development Bank of Latin America (CAF), which have expanded access to credit for their members. It is important that these institutions continue to provide low-cost, expeditious lines of credit, in addition to reviewing the conditionalities for emergency financing and adopting greater flexibility in their policies on concessional lending and the graduation of middle-income countries.

The fiscal space could be significantly expanded by debt forgiveness and relief, including for middle-income countries in the region that require it. Highly indebted economies must be allowed to benefit from official debt relief or generous debt standstills, as well as debt restructuring. It is urgent to address the debt problem and this effort must be led by official creditors, so that private creditors will then follow suit. Where debt is a structural feature of the respective economy, debt relief should be combined with innovative financing mechanisms. Given that most countries' creditors include some from the private sector, an international sovereign debt restructuring mechanism needs to be set up.

Other measures to expand the fiscal space and improve access to financing include revising procyclical fiscal rules and responsibility mechanisms - which focus only on spending and not on income - and prevailing upon rating agencies to factor into their risk assessment methodologies the fact that the deterioration in the countries' fiscal capacities to face the crisis is extraordinary and temporary.

The region's central banks have announced "non-conventional measures" to expand liquidity, including the purchase of public and private assets. This will require stronger coordination between fiscal and monetary authorities to finance the stimulus packages announced, either by directly purchasing securities issued by the public sector or by using external assets to finance increased spending.

Coordination among stakeholders is required to determine how and when to "normalize" monetary policy in the region. Greater coordination is also needed between fiscal and monetary policy, as well as between central banks and banking oversight and regulatory bodies, to ensure that these resources are channelled to households and productive sectors that need them and do not flow into the reserves of financial institutions or into external assets.

Given the magnitude of the shocks, it is necessary to adapt the macroprudential tools for mitigating exchange-rate volatility and excessive currency depreciations. Developing countries and emerging markets have found their access to foreign exchange, particularly to dollars, increasingly limited. The swap lines set up between the United States Federal Reserve and the central banks of Brazil and Mexico is a first step, but the rest of the region is not included in this support mechanism.

An additional way to expand access to dollar liquidity for all countries would be through the issuance of special drawing rights (SDRs) on a large scale, possibly even larger than in 2009, when IMF issued US\$2 250 billion in SDRs to help combat the global financial crisis, as proposed by the Group of Twenty (G20).

In this context, to address the socioeconomic impact of the crisis, ECLAC has proposed that governments guarantee temporary cash transfers to meet basic needs and support household consumption, which will be crucial to achieving recovery. From a long-term perspective, ECLAC reiterates that these transfers need to be ongoing, should reach beyond those living in poverty and cover broad strata of the population that are vulnerable to falling into poverty. This would make it 
possible to move towards a universal basic income that could be implemented gradually over a period suited to each country's situation.

Amid the COVID crisis, alternatives must be considered that have limited scope or duration, but which set the course for the measures that must be implemented once the pandemic is over. Given the limited fiscal space of the countries of the region, the most viable alternative in the current situation would be to transfer an amount equal to one poverty line for six months, which would cover a basic food basket and other basic needs. Such a measure would take additional expenditure of $2.8 \%$ of GDP to cover all those who will be living in poverty in 2020 . This configuration would need to be adjusted or expanded according to each national situation.

\section{Policies for structural change: creating the post-COVID world}

The pandemic has radically altered economic and social relations and its consequences will far outlast the health crisis. It is highly likely that the pandemic will accelerate changes that were already occurring in the configuration of global production and trade in the past decade. The model of globalization based on geographically highly dispersed international production networks was showing signs of depletion, for example in the secular stagnation of many economies, the loss of trade momentum and the great volatility seen since the global financial crisis. More recently, the unprecedented restrictions on international transport adopted by many countries have massively disrupted global value chains.

Since the outbreak of COVID-19, new global manufacturing orders have suffered the largest drop in 11 years. Although China has gradually resumed production, it faces supply-side constraints due to reduced imports from Europe and the United States, as well as very weak global demand. None of this points to a rapid recovery in global manufacturing. Global stocks of inputs fell sharply as a result of supply squeezes, with many countries reporting shortages of inputs, especially in sectors producing goods needed to respond to the health emergency.

In sum, the amplification of the production crisis has exposed the vulnerabilities of interdependence between countries and between firms, and may lead to significant changes in the global organization of production.

First, it has become apparent just how vulnerable international production networks are to large-scale unforeseen phenomena and, consequently, how much more resilient they need to be. For the multinational corporations at the core of these networks, this means diversifying networks of suppliers across countries and companies, preferably in locations closer to end markets (nearshoring), and relocating critical processes when economically feasible, through technologies such as additive manufacturing. There are already signs of movement in this direction in the world's major economies.

- Japan has allocated US\$2.2 billion of its COVID-19 economic stimulus package to helping its companies relocate production away from China.

- In the United States, the relocation rate peaked in 2019 amid trade tensions with China, while Mexico's share in United States manufacturing imports increased sharply relative to Asian suppliers (Kearney, 2020). The shocks caused by COVID-19 will likely accentuate both these trends.

- In the European Union, over 200 companies relocated their production between 2016 and 2019. Of these, $50 \%$ related to activities that had been offshored within the European Union itself, while China accounted for 32\% and India for 5\% (EUROFOUND, 2019). 
Second, the crisis has forced companies to adapt their internal operations to social distancing measures. As robotics, automation and the mass use of teleworking platforms become more efficient, cheaper and easier to implement, the automation of some sectors and production processes is likely to accelerate, with impacts on employment.

Third, with regard to global trade governance, COVID-19 has dealt a further blow to international cooperation and multilateralism, already weakened in recent years. Witness to this are the export restrictions on medical and health products and foodstuffs adopted by countries across all regions. In this context, and consistently with a scenario of shrinking international supply networks, the main players in global trade will likely turn their efforts towards regional —rather than multilateralagreements. Such a scenario would lead to more fragmented and conflict-ridden world trade, just when the ability of the World Trade Organization (WTO) to settle disputes among its members is already at its lowest ebb.

In short, the pandemic may be expected to reinforce existing trends towards less trade and production interdependence among the world's major economies, particularly between the United States and Europe on the one hand, and China on the other. This process will be facilitated by advances in digitization and robotization, which reduce the relative importance of low labour costs as a factor of competitiveness. The net result will not be the reversal of globalization, but a more regionalized world economy, organized around three existing production poles: North America, Europe, and East and South-East Asia.

For Latin America and the Caribbean, the magnitude of the impact and the response capabilities will depend largely on the production structure of each economy, on the depths of its firms' involvement in value chains and on existing production capacities.

As never before in the past 30 years, the region's prevailing model of engagement with the international economy — based on specialization in commodities, assembly manufacturing and sun and sea tourism - is open to discussion today. The disruption of several global value chains has shown the risks of heavy regional dependence on imported manufactures. This is particularly evident in the severe limitations on the supply of essential products for combating COVID-19, following restrictions imposed by most of the region's major suppliers. In this context, it is all the more important to roll out industrial and technological policies to enable the region to strengthen its productive capacities and generate new capabilities in strategic sectors. These efforts could be facilitated in some countries by new investment freed up by the shortening of the supply chains of multinational companies, especially in the United States.

In the international context that appears likely after COVID-19, production regionalization processes will be increasingly important. Regional integration will have a key role to play in the development strategies of the countries of Latin America and the Caribbean. An integrated market of 650 million people would act as major insurance against supply or demand shocks from outside the region. It would also help achieve the scale required to make new industries viable, and to foster shared production and research networks among the various countries and subregions.

Social protection is a key policy for reducing inequalities, making progress towards social inclusion and inclusive growth, and thus for achieving social cohesion. Countries thus need to consolidate universal social protection systems, including universal health, that are sensitive to differences and rooted in a rights-based approach, and to develop labour inclusion strategies in the recovery period. These systems make it possible to identify and respond to the impact of the crisis on people's employment and living conditions, and to address the situations faced by different population groups, paying timely attention to informal workers, the most vulnerable age groups, inhabitants of rural and remote areas, indigenous peoples, Afrodescendants, persons with disabilities and migrants.

To avoid another lost decade, the countries of the region must build welfare States and universal social protection systems. The international financial crisis of 2008 showed the importance of countercyclical public social spending and social policies aimed at moderating the effects of the 
crisis on real economies and curbing the rise in unemployment and poverty. By contrast, the debt crisis of the 1980s led to very significant increases in poverty. It took the region 25 years to bring poverty levels back to the (already high) pre-crisis rates. It is important to review these events because the increase in poverty projected by ECLAC for 2020 signifies a 13-year setback for the region (see figure 6).

\section{- Figure 6}

Latin America ( 18 countries): a per capita GDP and poverty levels, 1980-2020

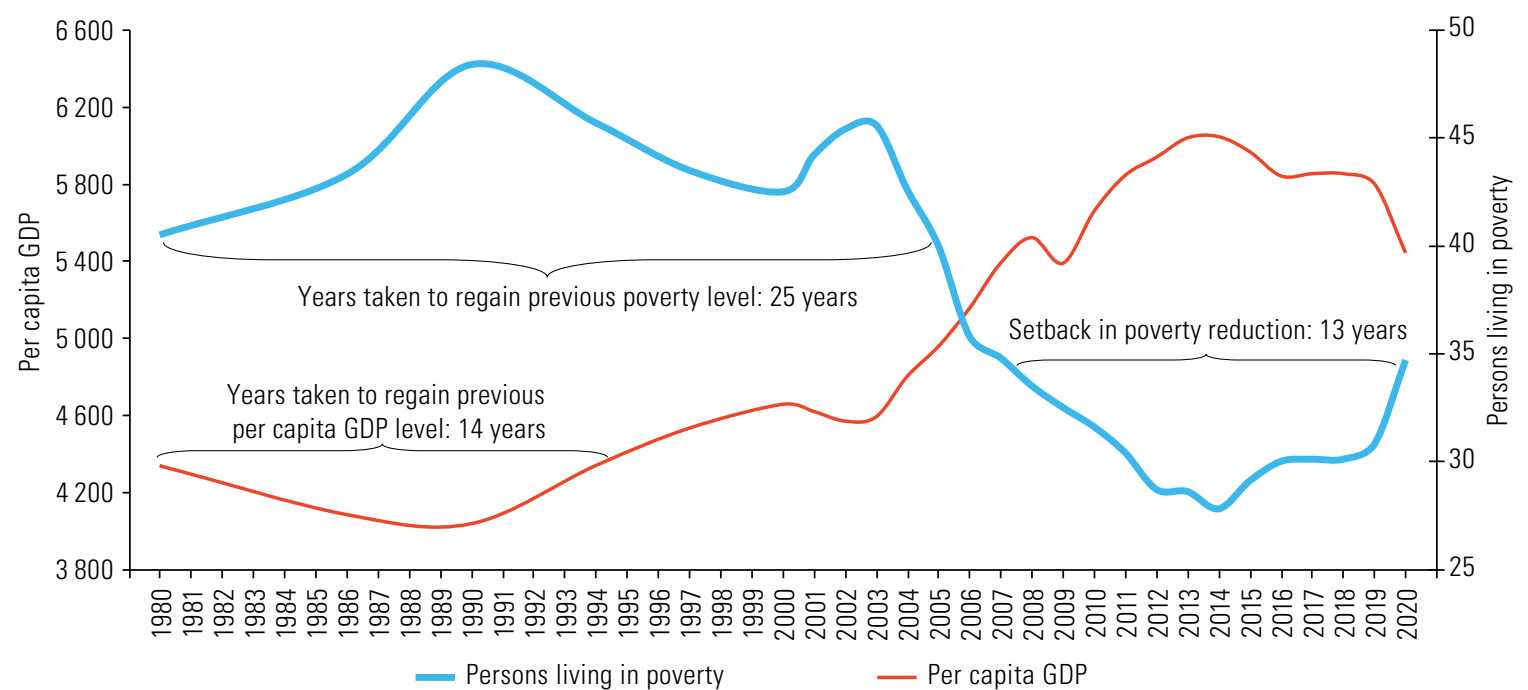

Source: Economic Commission for Latin America and the Caribbean (ECLAC), on the basis of the Household Survey Data Bank (BADEHOG).

a Argentina, Bolivarian Republic of Venezuela, Brazil, Chile, Colombia, Costa Rica, Dominican Republic, Ecuador, El Salvador, Guatemala, Honduras,

Mexico, Nicaragua, Panama, Paraguay, Peru, Plurinational State of Bolivia and Uruguay.

$\mathrm{b}^{\mathrm{b}}$ Figures for 2019 are preliminary. Figures for 2020 are projections.

\section{Conclusions -harsh, but clear}

- The region will suffer the worst crisis in its history in 2020, with a $5.3 \%$ drop in GDP. A contraction of comparable magnitude has not occurred since the Great Depression of the 1930s $(-5 \%)$ or even since $1914(-4.9 \%)$.

- The crisis will have major medium-term effects on the reorganization of production and international trade in terms of location and technology. At least three possible scenarios are still open: the continuation of globalization, but on the basis of new models of governance that are more receptive to multilateralism and the correction of inequalities between countries; solutions of exclusively national scope; or the strengthening of regionalization.

- For the great majority of Latin America and Caribbean countries, purely national solutions will not be viable owing to economies of scale, technology and learning.

- A new globalization with inclusive and sustainable governance may be the best solution, but in order to participate actively in this new configuration, Latin America and the Caribbean must achieve productive, trade and social integration. To this end, our countries must coordinate on macroeconomic and production matters in order to negotiate the conditions for the new normality. During the current crisis and also for the medium-term, financing for a new pattern of development with equality and environmental sustainability is of the essence. 


\section{E. Main policy recommendations}

- Supply an adequate fiscal stimulus to support health services and protect incomes and jobs. The uninterrupted supply of essential goods, in particular pharmaceuticals, medical equipment, food and energy, must be guaranteed, and universal access to testing and care must be ensured for all who need it. Although some countries have limited fiscal space, health spending is now a priority, especially in countries with weak and fragmented health-care systems.

- Strengthen social protection systems to support vulnerable populations: non-contributory programmes, such as direct cash transfers to the most vulnerable; unemployment, underemployment and self-employment benefits; interest-free loans to small and mediumsized enterprises to allow them to pay wages, and deferrals of loan, mortgage and rent payments. Measures such as suspension of payment of water, electricity and Internet bills for those on low incomes for the duration of the pandemic should be considered.

- In the current conditions, ECLAC calls for the implementation of an emergency basic income for an amount equal to one poverty line, for six months for the entire population living in poverty. The strategy over the medium and long terms should be geared towards establishing a welfare State with universal social protection.

- Central banks must safeguard firms' liquidity to remain in operation and the stability of the financial system. Expansionary monetary policies will not be enough; central banks should intervene directly to provide the liquidity needed by the financial and non-financial private sectors, in particular to ensure full liquidity in the overnight bank lending market and to avoid disruption of payment chains.

- International cooperation and multilateral organizations should design new technical and financial instruments to support countries facing fiscal pressures. They should also consider offering low-interest loans and debt relief and deferrals to open up the fiscal space. Developed and developing countries have very different means available to them to cope with this unprecedented crisis, which may exacerbate international inequalities. Some heavily indebted countries may have problems servicing, restructuring or increasing their debts because of the possible collapse of financial markets, which would undermine the much-needed public spending on health, social protection and economic stimulus. Countries must tailor their responses to local conditions, and those responses need to be bolstered by international cooperation. 


\section{Bibliography}

ECLAC (Economic Commission for Latin America and the Caribbean) (2020a), "Latin America and the Caribbean and the COVID-19 pandemic: economic and social effects", COVID-19 Special Report, No. 1, 3 April, Santiago. (2020b), "Measuring the impact of COVID-19 with a view to reactivation", COVID-19 Special Report, No. 2, 21 April, Santiago.

(2020c), "The social challenge in times of COVID-19", COVID-19 Special Report, No. 3, 12 May, Santiago. (2020d), The COVID-19 pandemic is exacerbating the care crisis in Latin America and the Caribbean, Santiago, April. (2019), Preliminary Overview of the Economies of Latin America and the Caribbean, 2019 (LC/PUB.2019/25-P), Santiago.

EUROFOUND (European Foundation for the Improvement of Living and Working Conditions) (2019), "European Reshoring Monitor" [online] https://reshoring.eurofound.europa.eu/.

Huenchuan, S. (2020), COVID-19: recomendaciones generales para la atención a personas mayores desde una perspectiva de derechos humanos (LC/MEX/TS.2020/6/Rev.1), Mexico City, Economic Commission for Latin America and the Caribbean (ECLAC).

IFF (Institute of International Finance) (2020a), "Global Debt Monitor: COVID-19 lights a fuse", 6 April [online] https://www.iif.com/Portals/0/Files/content/Research/Global\%20Debt\%20Monitor_April2020.pdf. (2020b), "LatAm views: deep recession", 13 April [online] https://www.iif.com/Portals/0/Files/content/ Research/04_13_2020_latam_views.pdf.

Kearney (2020), "Trade war spurs sharp reversal in 2019 Reshoring Index, foreshadowing COVID-19 test of supply chain resilience" [online] https://www.kearney.com/operations-performance-transformation/usreshoring-index.

United States Bureau of the Census (2018), "American Community Survey (ACS)" [online] https://www.census. gov/programs-surveys/acs.

UNWTO (World Tourism Organization) (2020), "Impact assessment of the COVID-19 outbreak on international tourism", 24 March [online] https://webunwto.s3.eu-west-1.amazonaws.com/s3fspublic/2020-03/2403Coronavirus.pdf.

WTO (World Trade Organization) (2020), "Trade forecast press conference", 8 April [online] https://www.wto. org/english/news_e/spra_e/spra303_e.htm. 
